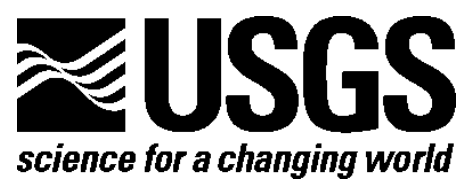

Prepared in cooperation with the U.S. Environmental Protection Agency

\title{
Air- and Stream-Water-Temperature Trends in the Chesapeake Bay Region, 1960-2014
}

By John D. Jastram and Karen C. Rice

Open-File Report 2015-1207

U.S. Department of the Interior

U.S. Geological Survey 


\section{U.S. Department of the Interior \\ SALLY JEWELL, Secretary}

\section{U.S. Geological Survey \\ Suzette M. Kimball, Acting Director}

U.S. Geological Survey, Reston, Virginia: 2015

For more information on the USGS-the Federal source for science about the Earth, its natural and living resources, natural hazards, and the environment-visit http://www.usgs.gov/ or call 1-888-ASK-USGS (1-888-275-8747).

For an overview of USGS information products, including maps, imagery, and publications, visit http://www.usgs.gov/pubprod/.

Any use of trade, firm, or product names is for descriptive purposes only and does not imply endorsement by the U.S. Government.

Although this information product, for the most part, is in the public domain, it also may contain copyrighted materials as noted in the text. Permission to reproduce copyrighted items must be secured from the copyright owner.

Suggested citation:

Jastram, J.D., and Rice, K.C., 2015, Air- and stream-water-temperature trends in the Chesapeake Bay region, 1960-2014: U.S. Geological Survey Open-File Report 2015-1207, 28 p., http://dx.doi.org/10.3133/ofr20151207.

ISSN 2331-1258 (online) 


\section{Preface}

This report documents an update to the air-temperature and stream-water-temperature trend analyses presented in Rice and Jastram (2015). This update extends the analysis period (1960-2010) to include data collected through the end of the 2014 water year (September 30, 2014). Methods of analysis are presented in Rice and Jastram (2015). This updated analysis was performed for inclusion of air-temperature and stream-water-temperature trends as indicators of climate change in the U.S. Environmental Protection Agency's "Climate Change Indicators in the United States, 2016" report.

\section{Acknowledgments}

The authors thank the cooperator, the U.S. Environmental Protection Agency, for support of this scientific work. In particular, we thank Michael Kolian for initiating this effort and for his contributions to the report. Thorough reviews were provided by James Webber and John Clune, U.S. Geological Survey, whose comments improved the clarity of the report. 


\section{Contents}

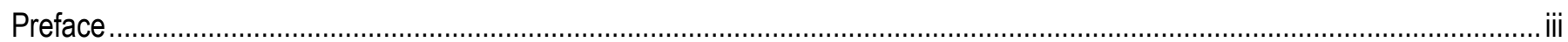

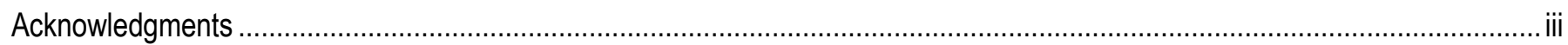

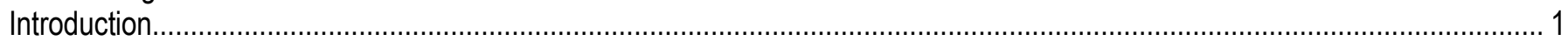

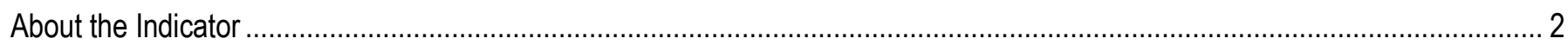

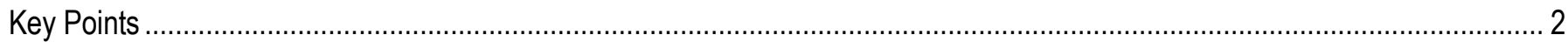

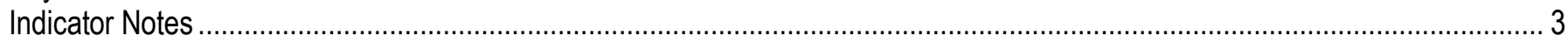

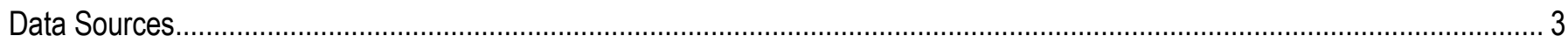

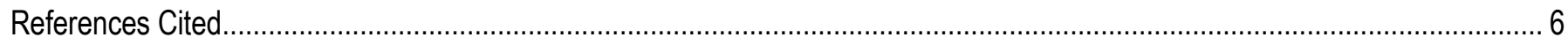

Appendix 1. Air-temperature station information and results of trend analyses, Chesapeake Bay region, 1960-2014 ................ 7

Appendix 2. Water-temperature station information and results of trend analyses, Chesapeake Bay region,1960-2014 ..........11

Appendix 3. Timeseries plots of air-temperature anomalies with trend lines, Chesapeake Bay region, 1960-2014 ................. 19

Appendix 4. Timeseries plots of stream-water-temperature anomalies with trend lines, Chesapeake Bay region, 1960-2014 ...19

\section{Figures}

Figure 1. Map showing locations of air-temperature measurement stations and results of trend analyses at those stations, Chesapeake Bay region, 1960-2014.

Figure 2. Map showing locations of stream-water-temperature measurement stations and results of trend analyses at those stations, Chesapeake Bay region, 1960-2014.....

Figure 3. Plots of non-exceedance probabilities and model significance for air- and stream-watertemperature trends, Chesapeake Bay region, 1960-2014

Table

Table 1. Summary of trend-analysis results for air and stream-water temperature, Chesapeake Bay region, 1960-2014 . 


\section{Conversion Factors}

Temperature in degrees Celsius $\left({ }^{\circ} \mathrm{C}\right)$ may be converted to degrees Fahrenheit $\left({ }^{\circ} \mathrm{F}\right)$ as ${ }^{\circ} \mathrm{F}=\left(1.8 \times{ }^{\circ} \mathrm{C}\right)+32$.

Temperature in degrees Fahrenheit $\left({ }^{\circ} \mathrm{F}\right)$ may be converted to degrees Celsius $\left({ }^{\circ} \mathrm{C}\right)$ as ${ }^{\circ} \mathrm{C}=\left({ }^{\circ} \mathrm{F}-32\right) / 1.8$.

\section{Datum}

Vertical coordinate information is referenced to the North American Vertical Datum of 1988 (NAVD 88).

Horizontal coordinate information is referenced to the North American Datum of 1983 (NAD 83).

\section{Abbreviations}

AT

Air temperature

EPA U.S. Environmental Protection Agency

NOAA National Atmospheric and Oceanic Administration

USGS U.S. Geological Survey

WT Water temperature 



\title{
Air- and Stream-Water-Temperature Trends in the Chesapeake Bay Region, 1960-2014
}

\author{
By John D. Jastram and Karen C. Rice
}

\section{Introduction}

Water temperature is a basic, but important, measure of the condition of all aquatic environments, including the flowing waters in the streams that drain our landscape and the receiving waters of those streams. Climatic conditions have a strong influence on water temperature, which is therefore naturally variable both in time and across the landscape. Changes to natural watertemperature regimes, however, can result in a myriad of effects on aquatic organisms, water quality, circulation patterns, recreation, industry, and utility operations. For example, most species of fish, insects, and other organisms, as well as aquatic vegetation, are highly dependent on water temperature. Warming waters can result in shifts in floral and faunal species distributions (Short and Neckles, 1999; Beitinger and others 2000; Coles and Jones, 2000), including invasive species and pathogens previously unable to inhabit the once cooler streams. Many chemical processes are temperature dependent, with reactions occurring faster in warmer conditions, leading to degraded water quality as contaminants are released into waterways at greater rates (Duan and Kaushal, 2013). Circulation patterns in receiving waters, such as bays and estuaries, can change as a result of warmer inflows from streams, thereby affecting organisms in those receiving waters. Changes in abundance of some aquatic species and (or) degradation of water quality can reduce the recreational value of water bodies as waters are perceived as less desirable for water-related activities or as sportfish become less available for anglers. Finally, increasing water temperatures can affect industry and utilities as the thermal capacity is reduced, making the water less effective for cooling purposes.

Chesapeake Bay is the largest estuary in the United States. Eutrophication, the enrichment of a water body with excess nutrients, has plagued the bay for decades and has led to extensive restoration efforts throughout the bay watershed. The warming of stream water can exacerbate eutrophication through increased release of nutrients from in-stream sediments (Duan and Kaushal, 2013), so understanding changes in stream-water temperature throughout the bay watershed is critical to resource managers seeking to restore the bay ecosystem.

The U.S. Environmental Protection Agency (EPA) uses indicators that "represent the state or trend of certain environmental or societal conditions ... to track and better understand the effects of changes in the Earth's climate" (U.S. Environmental Protection Agency, 2014). Updates to these indicators are published biennially by the EPA. The U.S. Geological Survey (USGS), in cooperation with the EPA, has completed analyses of air- and stream-water-temperature trends in the Chesapeake Bay region to be included as an indicator in a future release of the EPA report. 


\section{About the Indicator}

The National Oceanic and Atmospheric Administration (NOAA) operates meteorological monitoring stations, which routinely measure air temperature (AT) and other meteorological variables, throughout the United States. The AT trends for this indicator are determined from monthly mean AT data for the period January 1, 1960, through September 30, 2014, from 79 NOAA meteorological monitoring stations located within or near the Chesapeake Bay watershed. The U.S. Geological Survey (USGS) measures streamflow in rivers and streams across the United States at monitoring stations called streamgages, and stream-water temperature (WT) is measured periodically at these stations. The WT trends for this indicator are determined from instantaneous WT data collected from January 1, 1960, through September 30, 2014, at 129 streamgages within or near the Chesapeake Bay watershed. Methods of data acquisition, processing, and analysis are described in Rice and Jastram (2015).

This indicator includes evaluations of AT and WT trends within or near the Chesapeake Bay watershed for the nearly 55-year period of 1960-2014. The direction, magnitude, and statistical significance of AT (fig. 1) and WT (fig. 2) trends are shown on maps. Station location and trendanalysis details for individual AT and WT stations are provided in appendixes 1 and 2, respectively, and plotted in in appendixes 3 and 4, respectively.

\section{Key Points}

- From 1960 through 2014, AT increased significantly at 63 of 79 stations analyzed within and near the Chesapeake Bay watershed, and decreased significantly at 4 stations (table 1; fig. 3).

- Regionally, the median of significant AT trends was 0.020 degree Celsius $\left({ }^{\circ} \mathrm{C}\right)$ per year with a range of -0.02 to $0.04^{\circ} \mathrm{C}$.

- Trends in AT were relatively consistent throughout the study area.

- From 1960 through 2014, WT increased significantly at 53 of 129 stations analyzed in the region. Stream-water temperature decreased significantly at 7 of those 129 stations over the same period.

- Regionally, the median of significant WT trends was $0.026^{\circ} \mathrm{C}$ per year with a range of -0.08 to $0.08^{\circ} \mathrm{C}$ per year.

- Increases in WT occurred at the greatest rates in the southern part of the study area.

- Compared to AT trend results for data spanning 1960-2010 (Rice and Jastram, 2015), two more stations had significantly increasing trends during the period 1960-2014, and one more station had a significantly decreasing trend during the period 1960-2014.

- Compared to WT trend results for data spanning 1960-2010 (Rice and Jastram, 2015), four more stations had significantly increasing trends during the period 1960-2014, and one less station had a significantly decreasing trend during the period 1960-2014. 
Table 1. Summary of trend-analysis results for air and stream-water temperature, Chesapeake Bay region, 1960-2014.

\begin{tabular}{lccccc}
\hline \multicolumn{1}{c}{ Statistic } & \multicolumn{2}{c}{ Air temperature } & \multicolumn{2}{c}{ Water temperature } \\
& 1960-2014 & 1960-2010 & 1960-2014 & 1960-2010 a \\
\hline Number of stations & $79^{\mathrm{b}}$ & 85 & 129 & 129 \\
$\begin{array}{l}\text { Number of significant trends } \\
\text { Number of significant increasing }\end{array}$ & 67 & 64 & 60 & 57 \\
$\quad \begin{array}{l}\text { Number } \\
\quad \text { decreasing trends }\end{array}$ & 63 & 61 & 53 & 49 \\
$\begin{array}{l}\text { Range of trends, in degrees } \\
\quad \text { Celsius per year }\end{array}$ & $-0.022-0.045$ & $-0.018-0.057$ & $-0.080-0.081$ & $-0.095-0.095$ \\
Median of significant trends & 0.020 & 0.023 & 0.026 & 0.028 \\
\hline
\end{tabular}

${ }^{a}$ From Rice and Jastram, 2015.

${ }^{\mathrm{b}}$ Six of the 85 stations were discontinued between 2010 and 2014.

\section{Indicator Notes}

Water temperature in streams can be affected by factors other than climate, including industrial discharges, hydrologic alteration (for example, channelization, piping, and impoundment), land cover, location, and topography. For this indicator, WT measurements from all available streamgages with appropriate records within the study area were used, as described in Rice and Jastram (2015), regardless of potential influences from anthropogenic disturbances. A comparison, using the Rank-Sum test (Helsel and Hirsch, 2002), of relatively undisturbed reference stations $(n=35)$, as determined by Falcone (2011), with all other stations $(\mathrm{n}=94)$ in the dataset demonstrated no significant difference $($ alpha $=0.05)$ in trends between the two groups of stations.

\section{Data Sources}

AT data were collected by NOAA and were downloaded from the National Centers for Environmental Information Web site (http://www.ncdc.noaa.gov). WT data were collected by the USGS and were retrieved from the National Water Information System. These data are from stations selected according to the criteria described in Rice and Jastram (2015). 


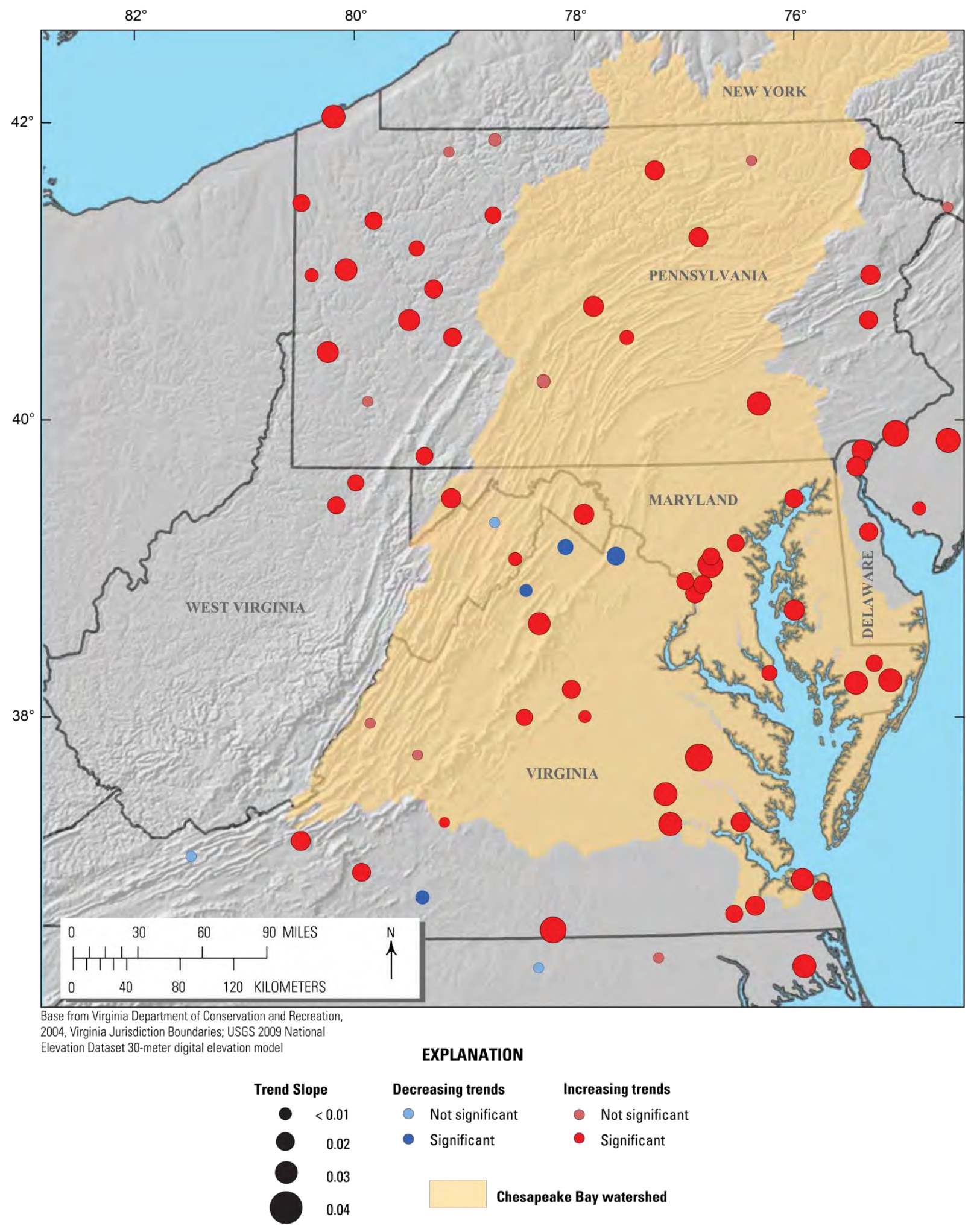

Figure 1. Locations of air-temperature measurement stations and results of trend analyses at those stations, Chesapeake Bay region, 1960-2014. 


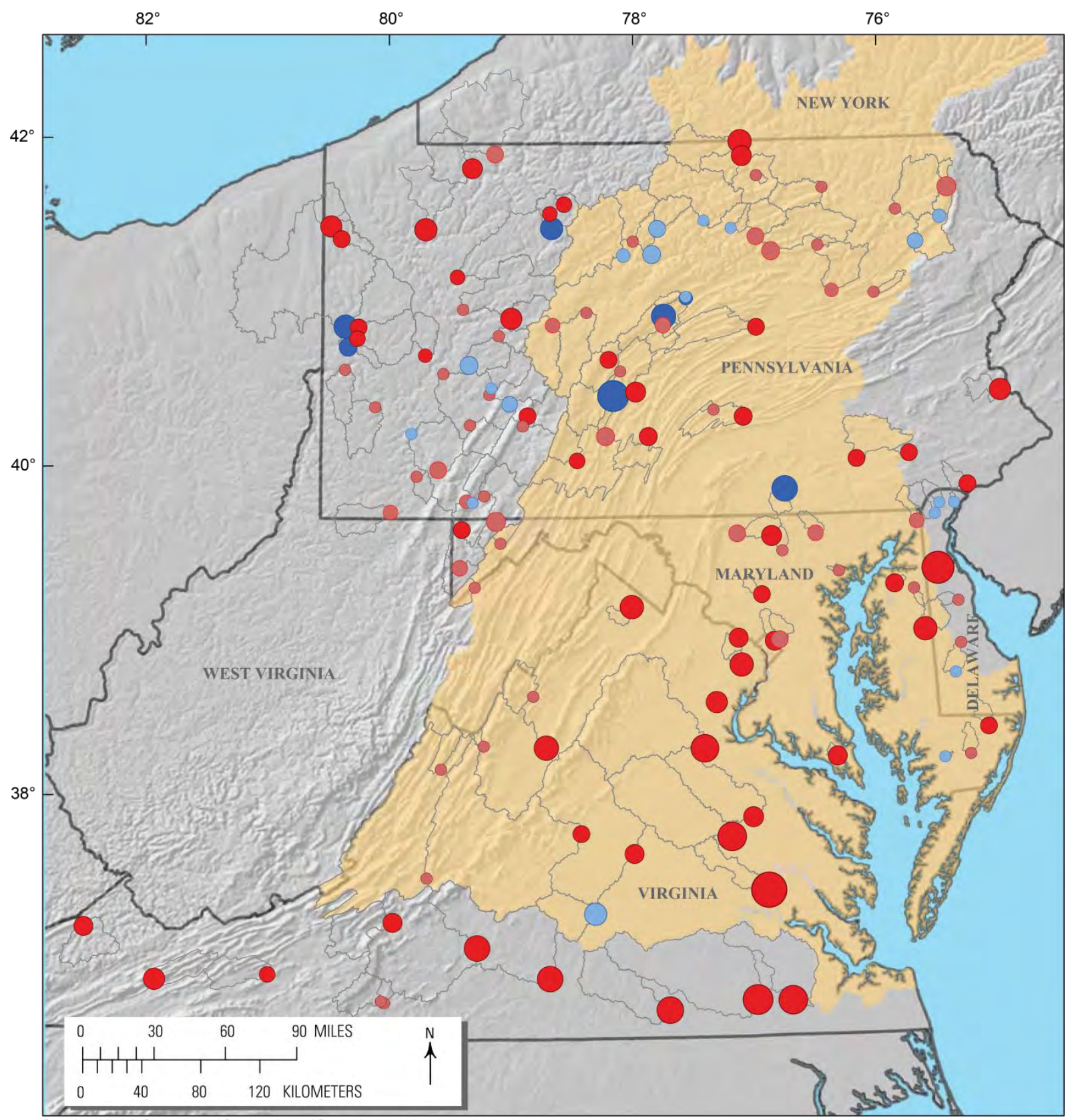

Base from Virginia Department of Conservation and Recreation, 2004, Virginia Jurisdiction Boundaries; USGS 2009 National Elevation Dataset 30-meter digital elevation model

EXPLANATION

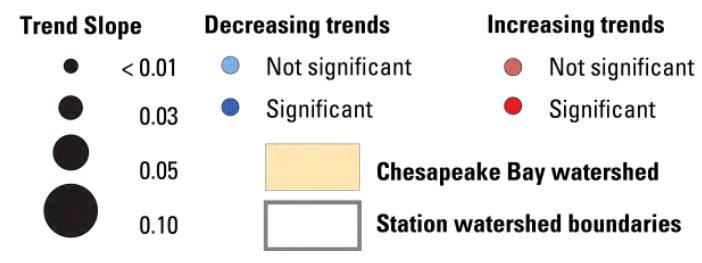

Figure 2. Locations of stream-water-temperature measurement stations and results of trend analyses at those stations, Chesapeake Bay region, 1960-2014. 


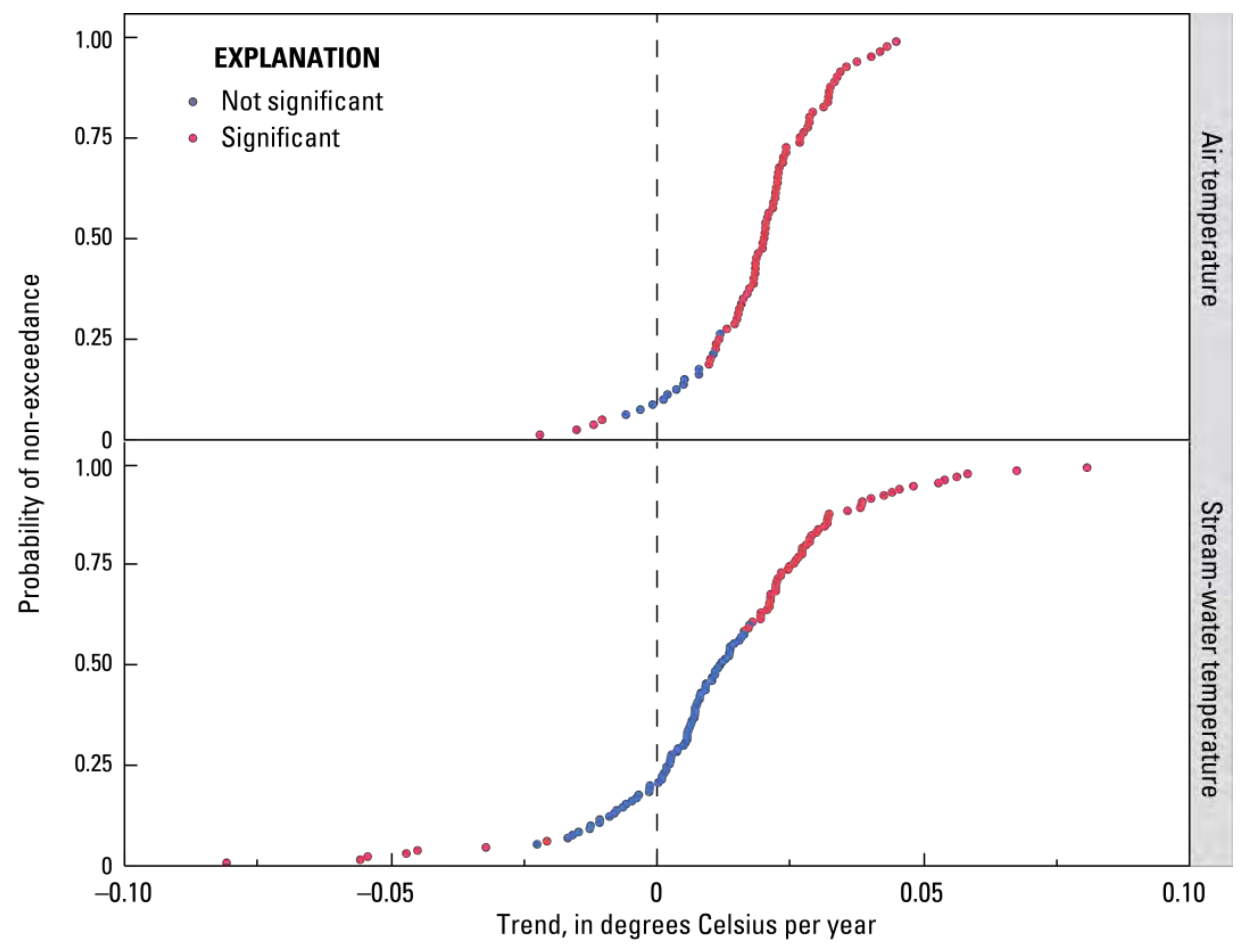

Figure 3. Non-exceedance probabilities and model significance for air- and stream-water-temperature trends, Chesapeake Bay region, 1960-2014.

\section{References Cited}

Beitinger, T.L., Bennett, W.A., and McCauley, R.W., 2000, Temperature tolerances of North American freshwater fishes exposed to dynamic changes in temperature: Environmental Biology of Fishes, v. 58, no. 3, p. 237-275.

Coles, J.F., and Jones, R.C., 2000, Effect of temperature on photosynthesis-light response and growth of four phytoplankton species isolated from a tidal freshwater river: Journal of Phycology, v. 36, no. 1, p. 7-16.

Duan, S.W., and Kaushal, S.S., 2013, Warming increases carbon and nutrient fluxes from sediments in streams across land use: Biogeosciences, v. 10, no. 2, p. 1193-1207.

Falcone, J.A., 2011, GAGES-II, Geospatial Attributes of Gages for Evaluating Streamflow [digital spatial dataset], accessed August 5, 2015, at http://water.usgs.gov/GIS/metadata/usgswrd/XML/ gagesII_Sept2011.xml.

Helsel, D.R., and Hirsch, R.M., 2002, Statistical methods in water resources: U.S. Geological Survey Techniques of Water-Resources Investigations, book 4, chap. A3, 523 p.

Rice, K.C., and Jastram, J.D., 2015, Rising air and stream-water temperatures in Chesapeake Bay region, USA: Climatic Change, v. 128, no. 1, p. 127-138.

Short, F.T., and Neckles, H.A., 1999, The effects of global climate change on seagrasses: Aquatic Botany, v. 63, no. 3-4, p. 169-196.

U.S. Environmental Protection Agency, 2014, Climate change indicators in the United States, 2014 (3d ed.): EPA 430-R-14-004, accessed August 17, 2015, at http://www.epa.gov/climatechange/indicators. 


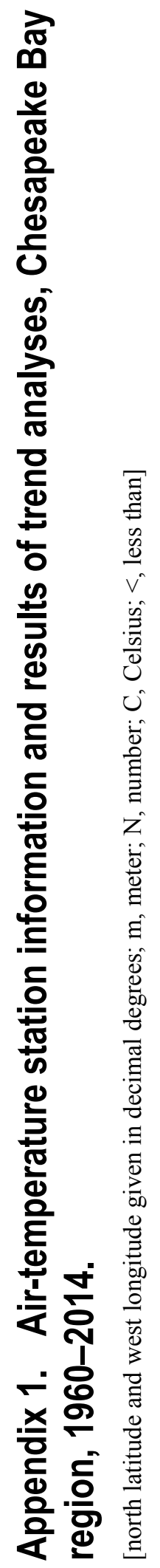

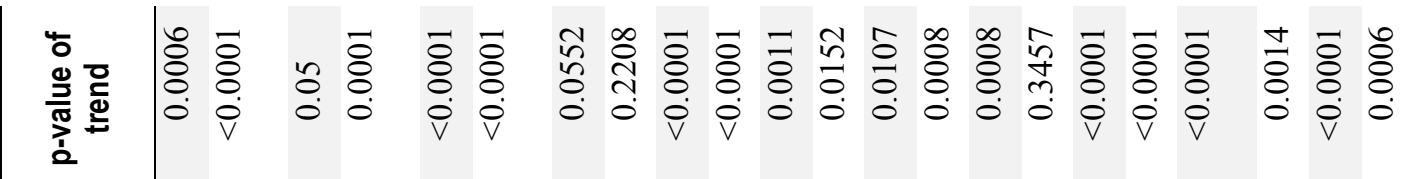

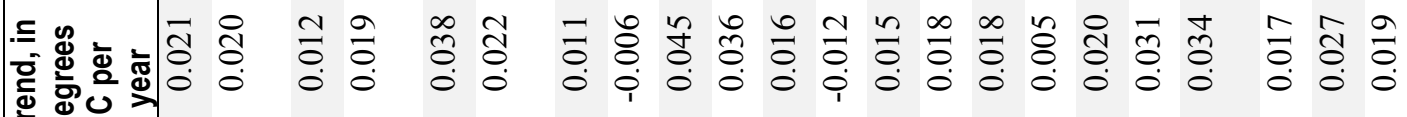
는

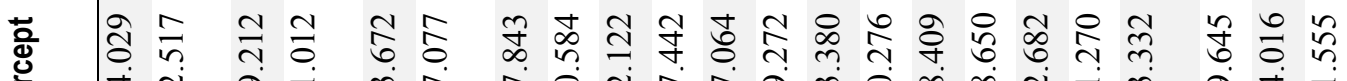

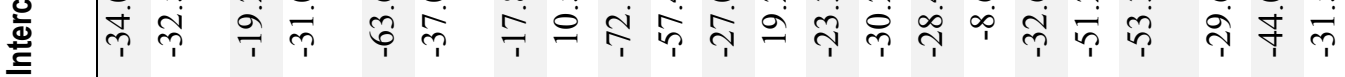

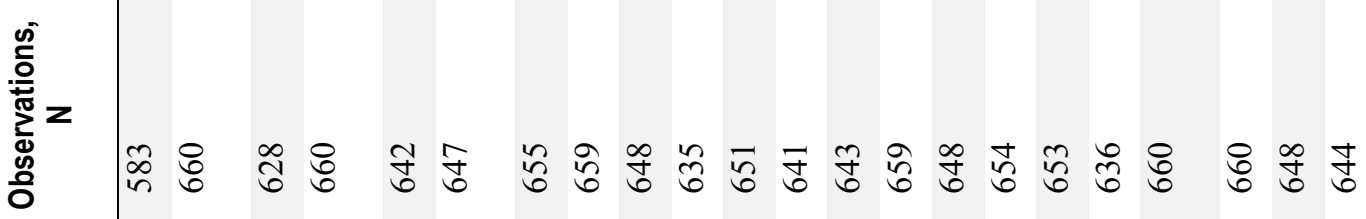

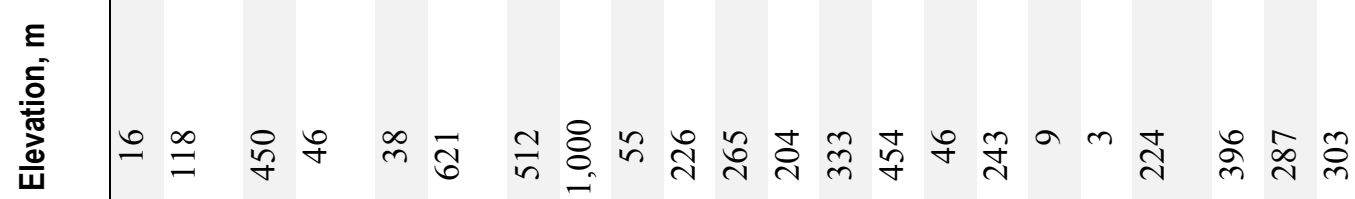

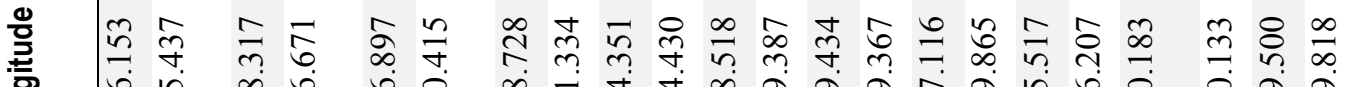
可

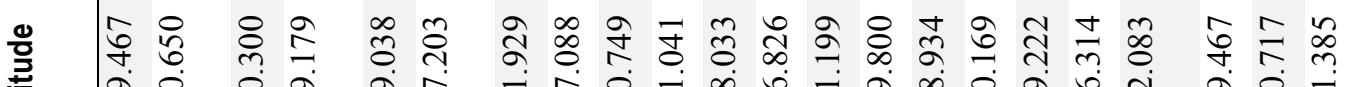

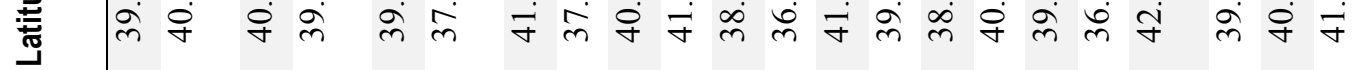

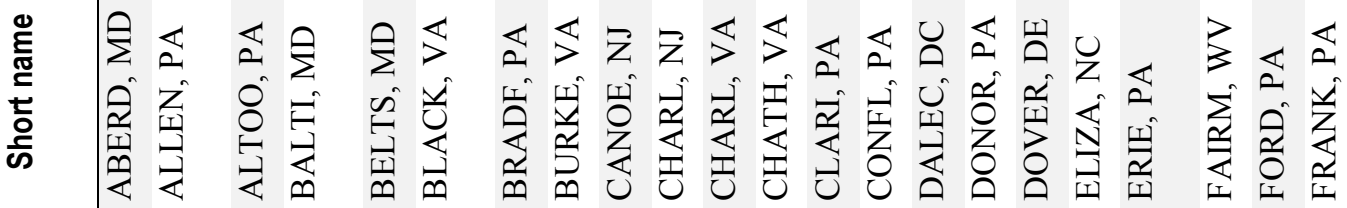

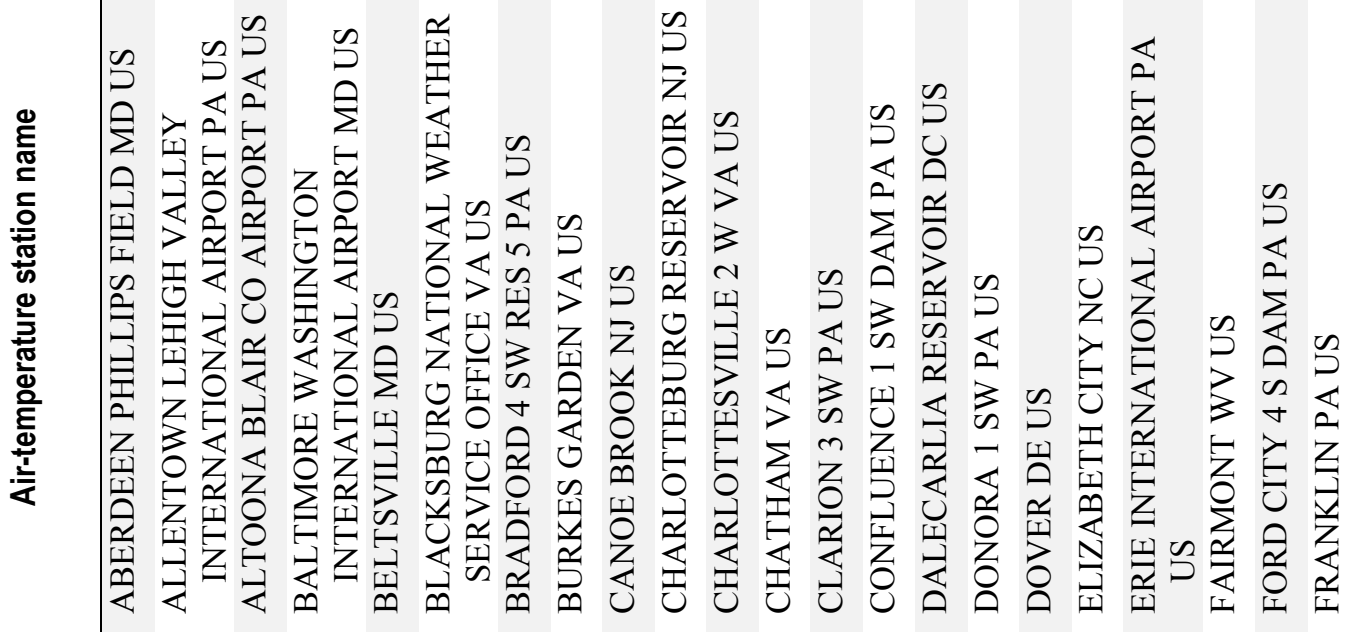



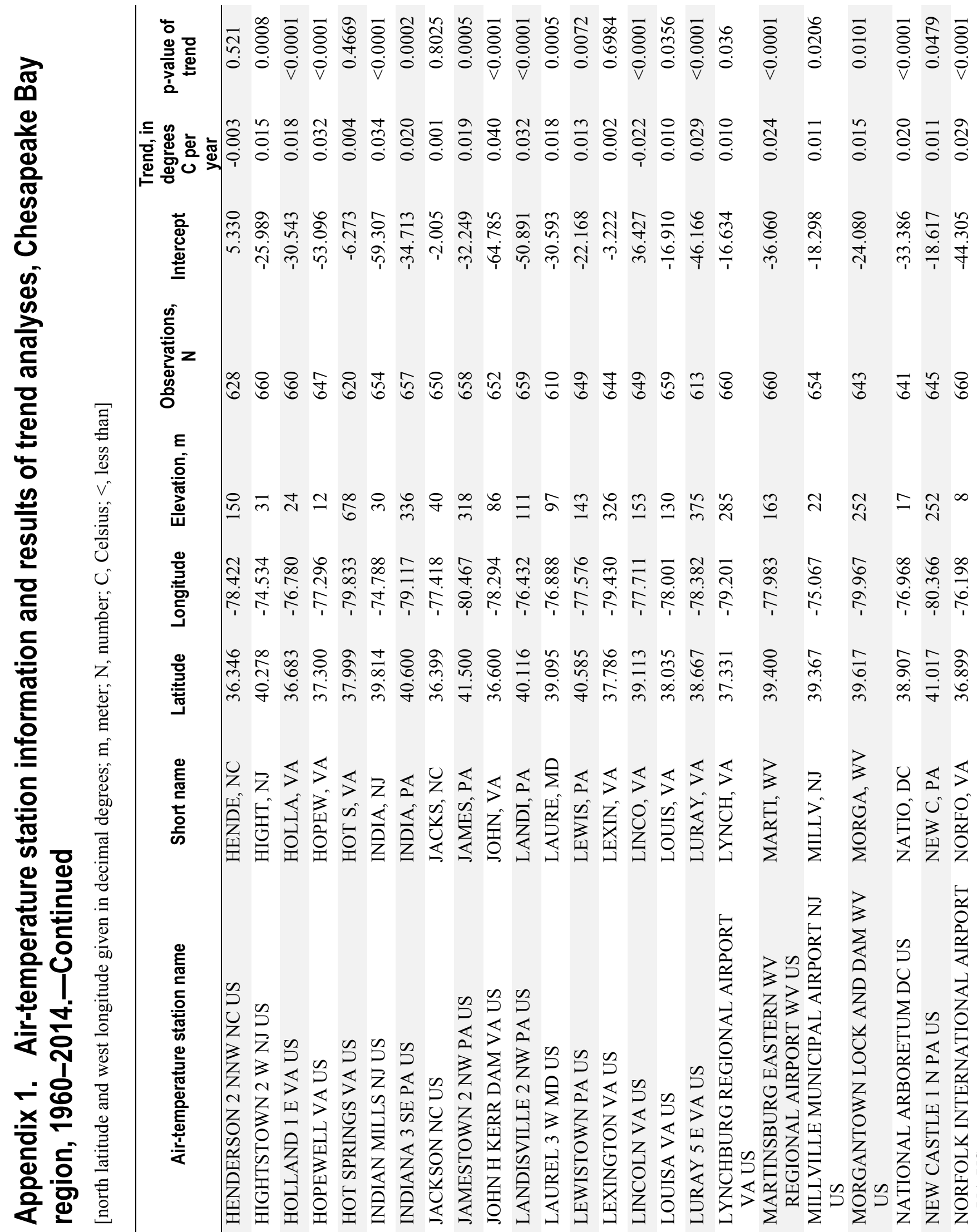

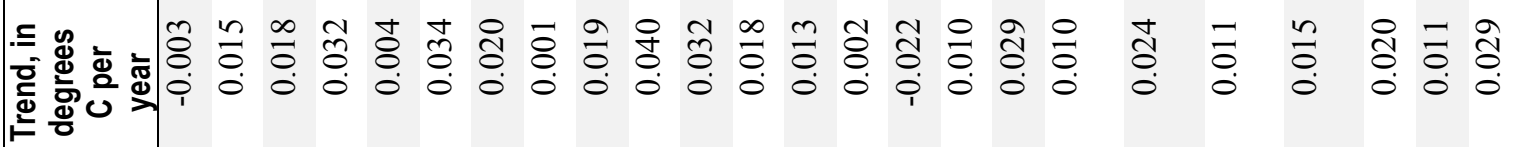

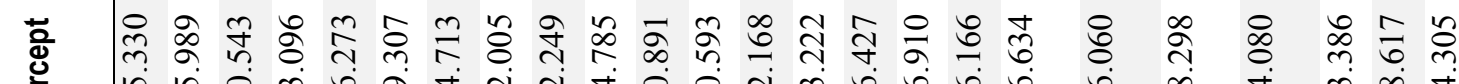

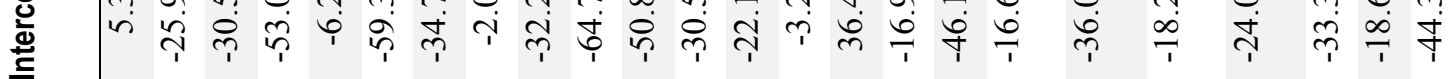

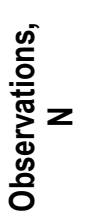

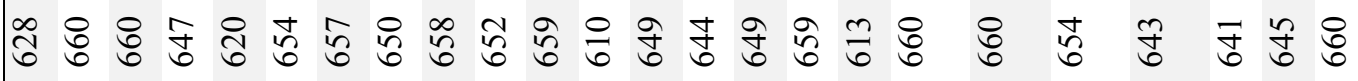

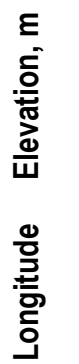

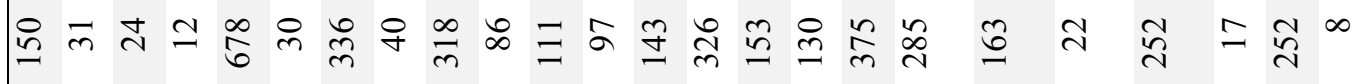

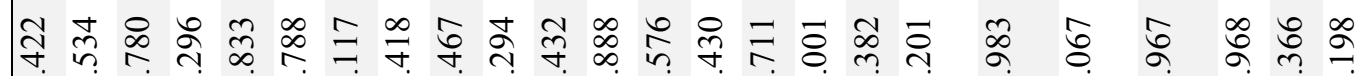

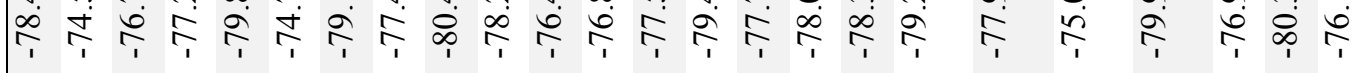

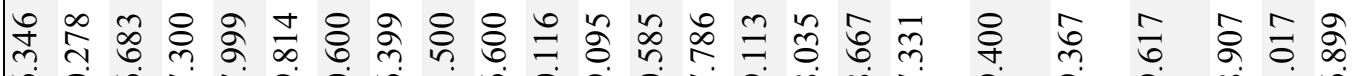

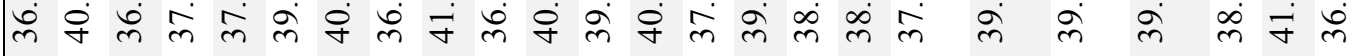

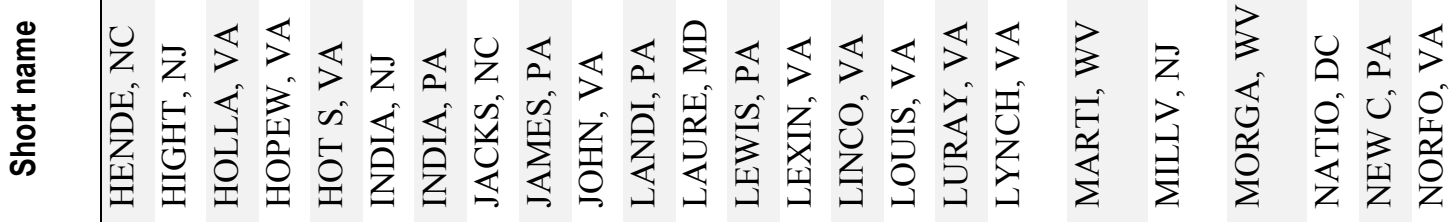

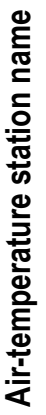

$\tilde{D}$

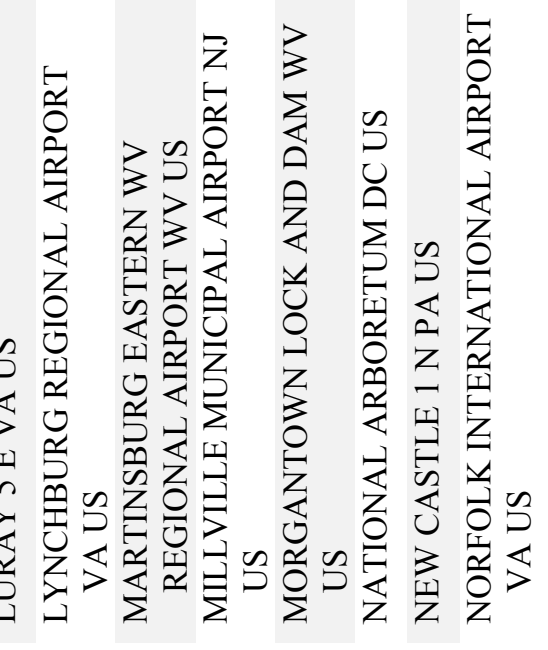



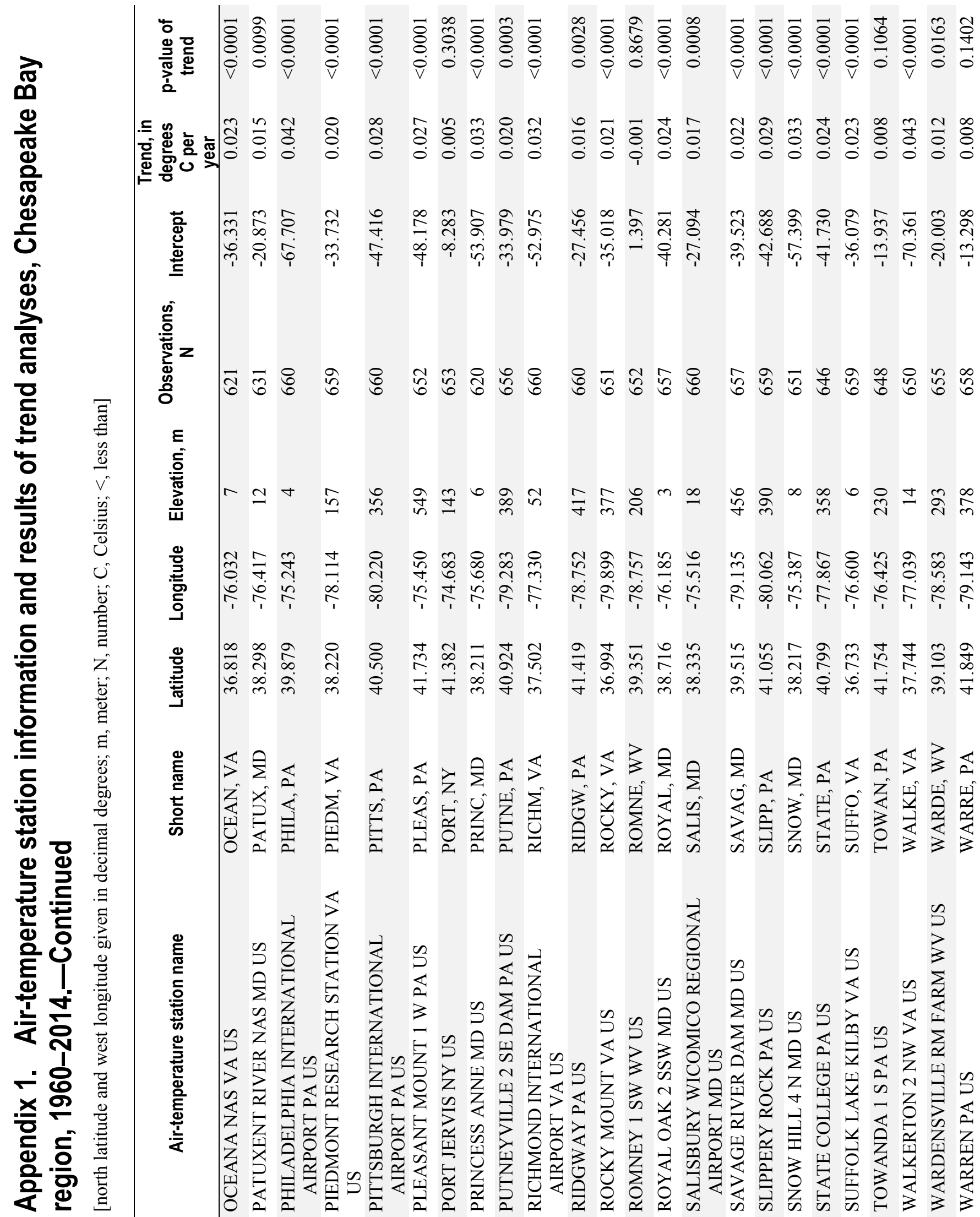

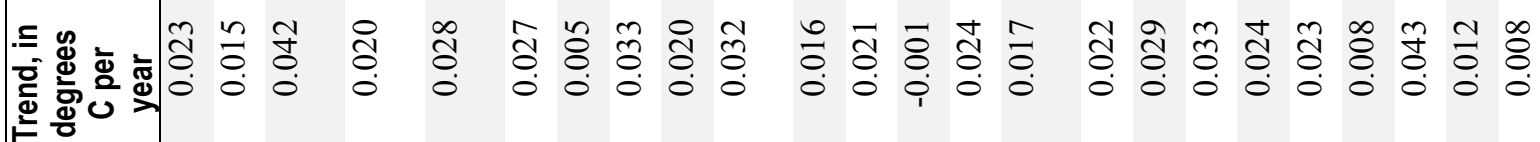

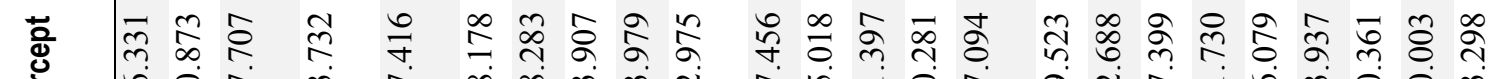
总

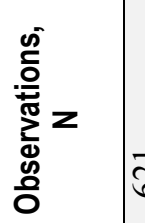

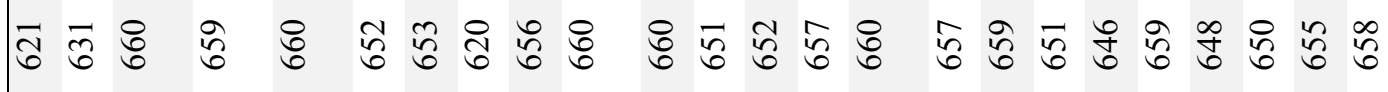
|

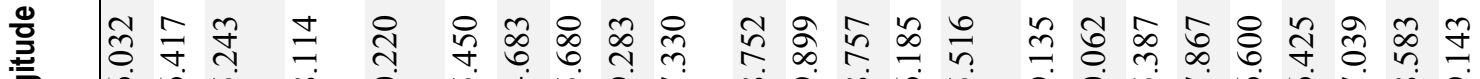
可

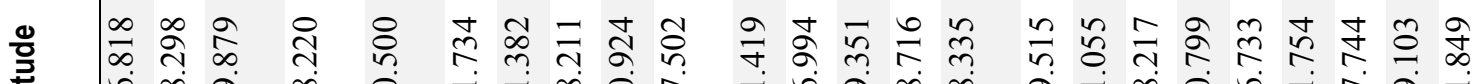

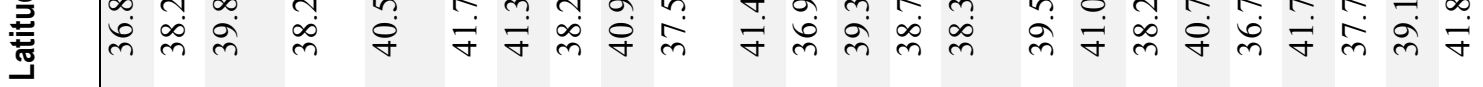

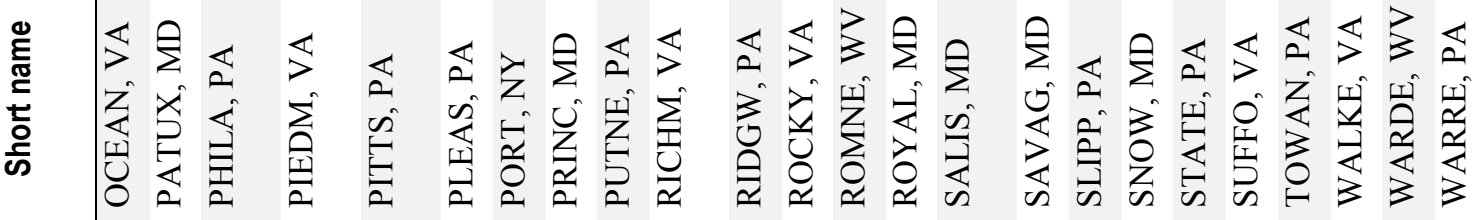

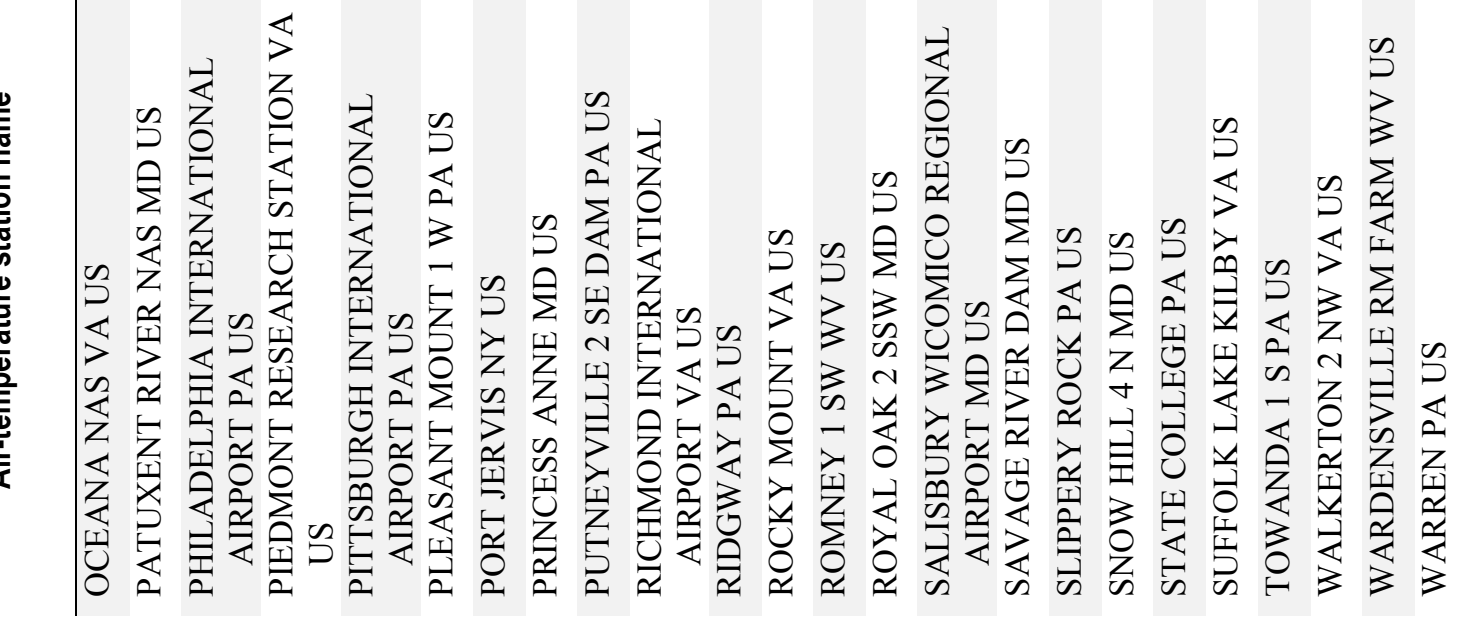




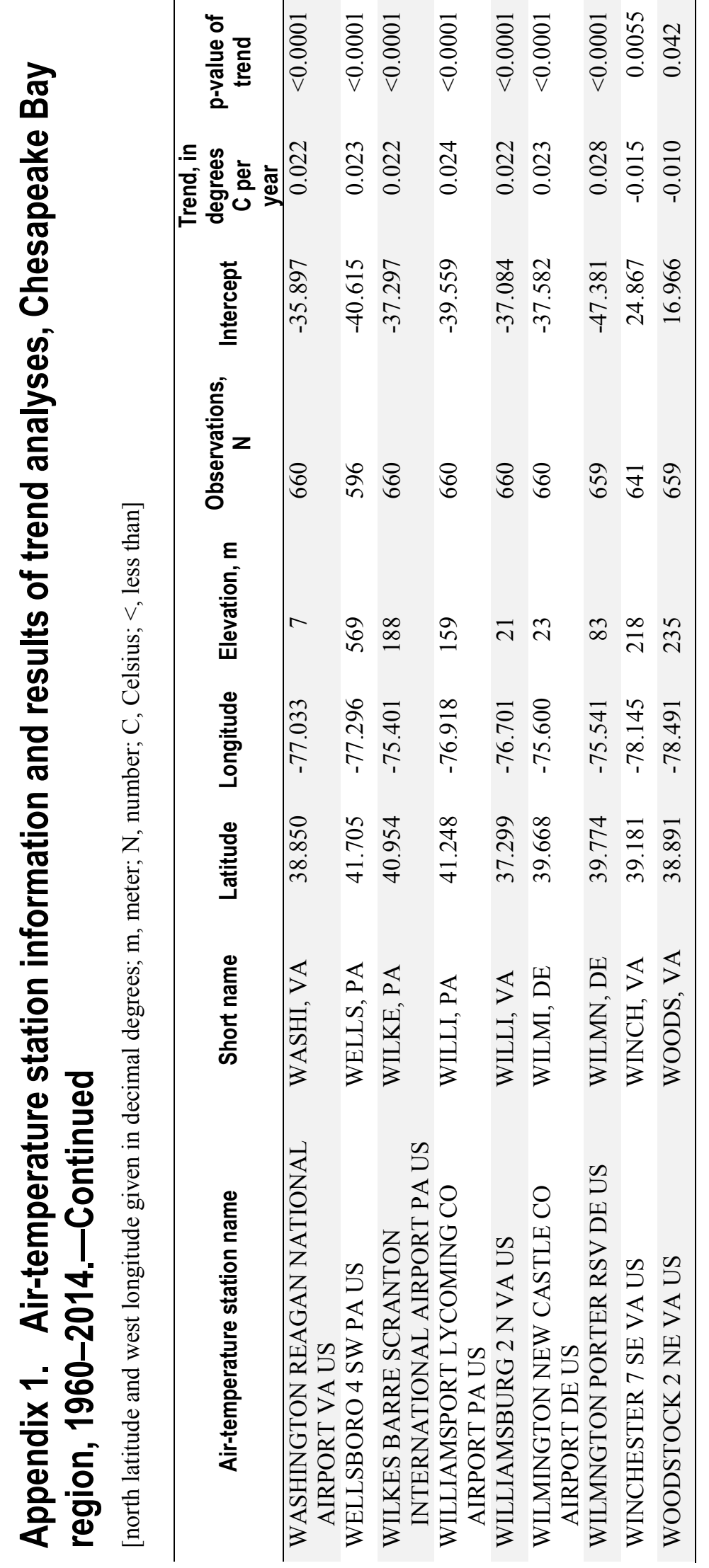




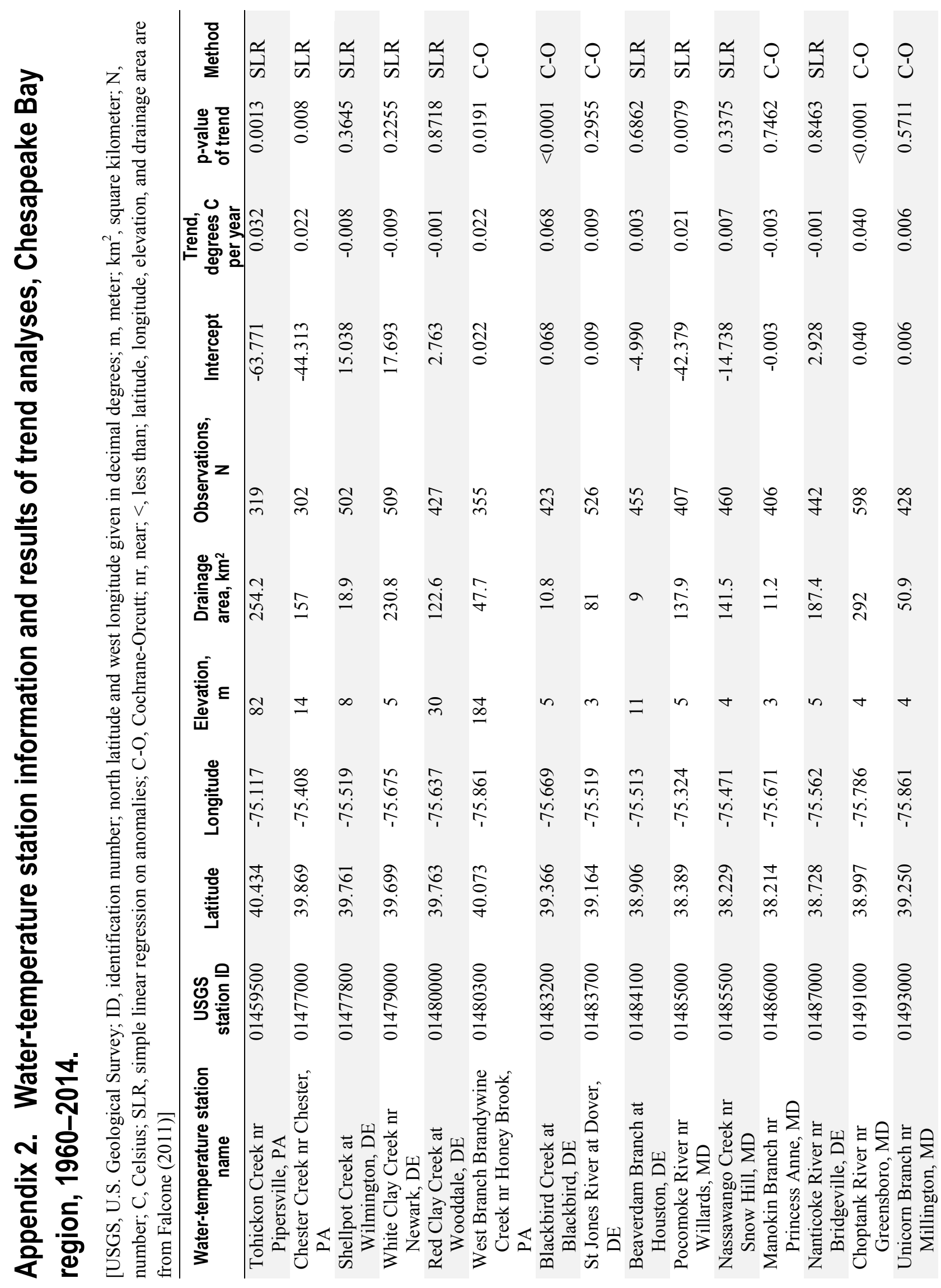




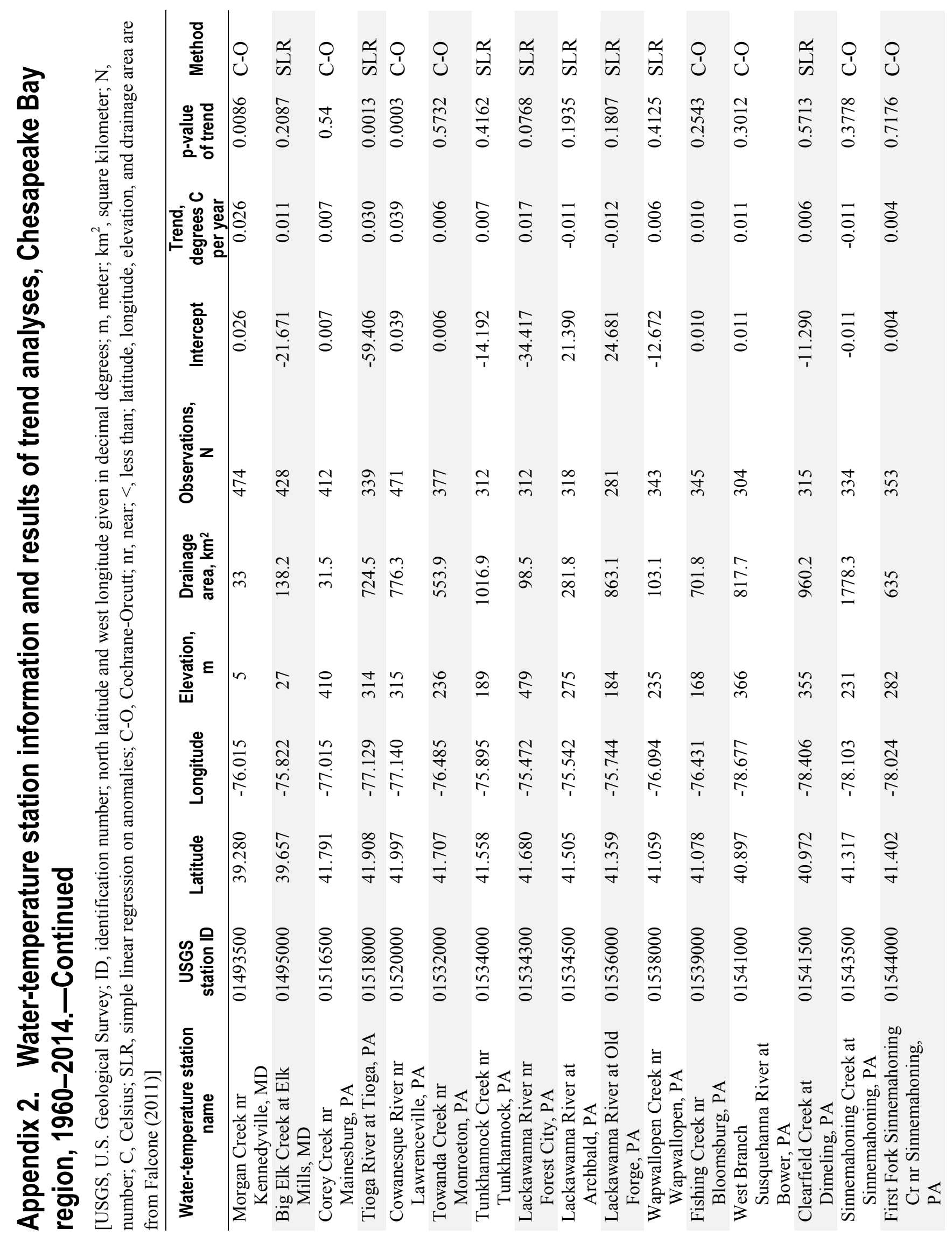




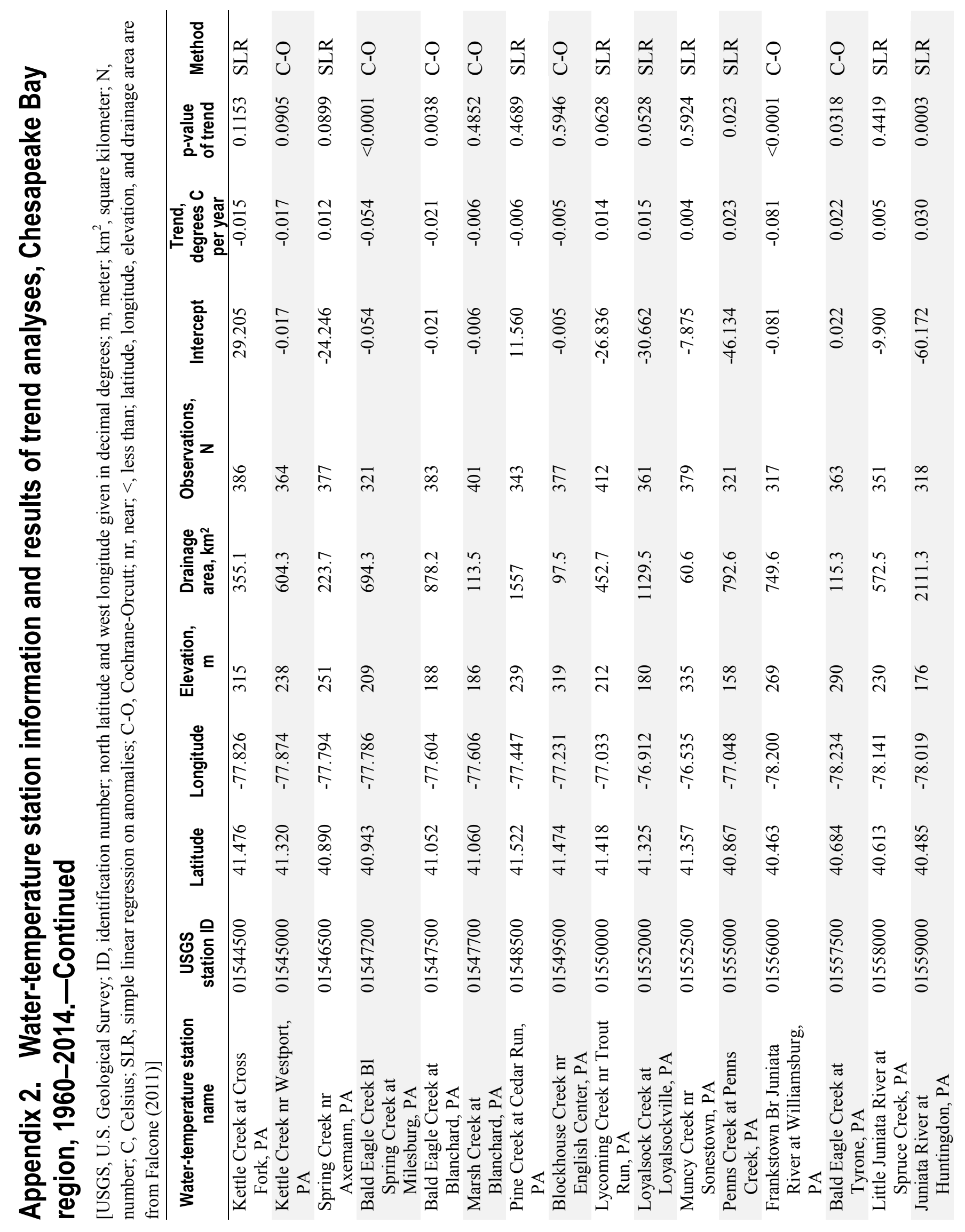




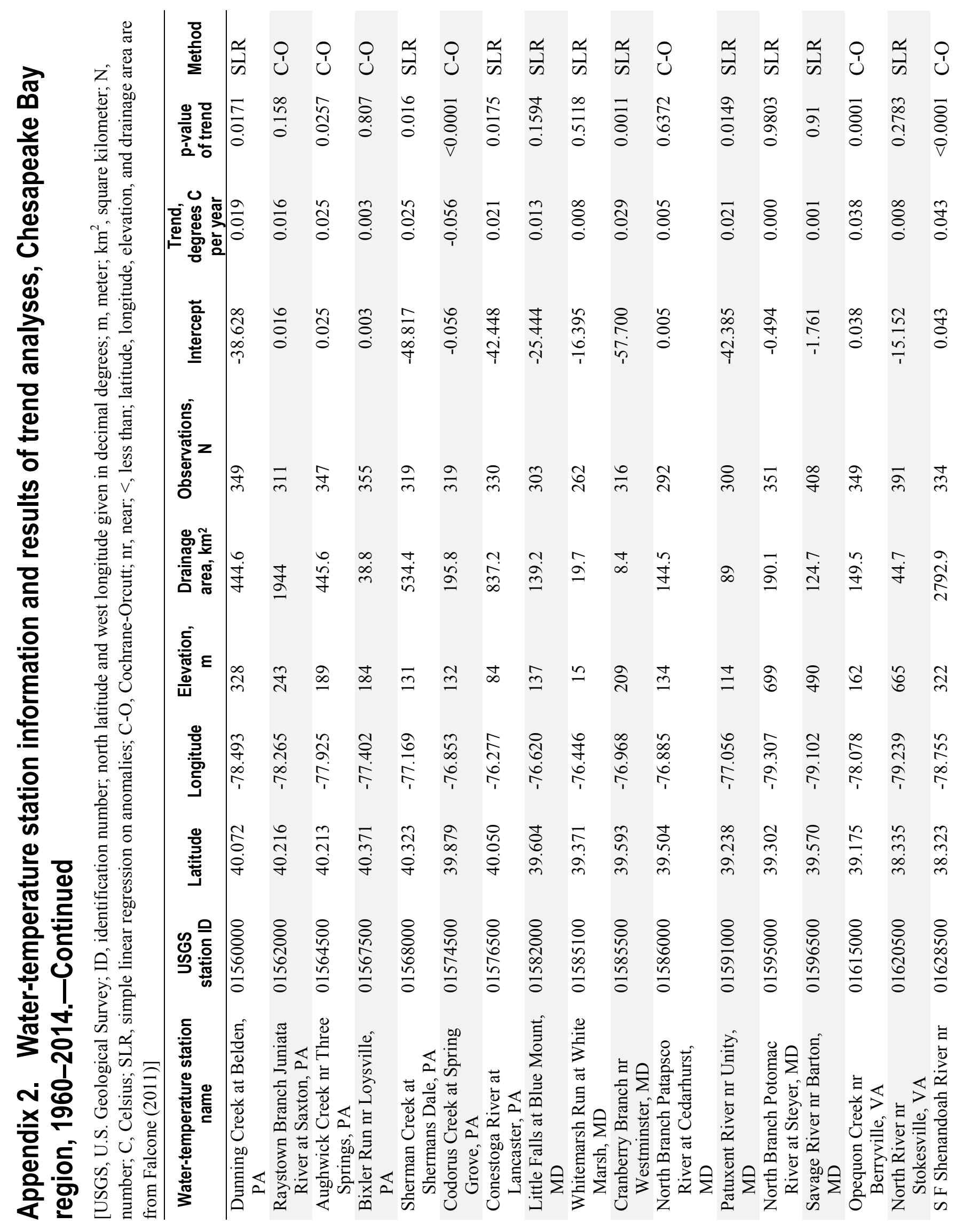




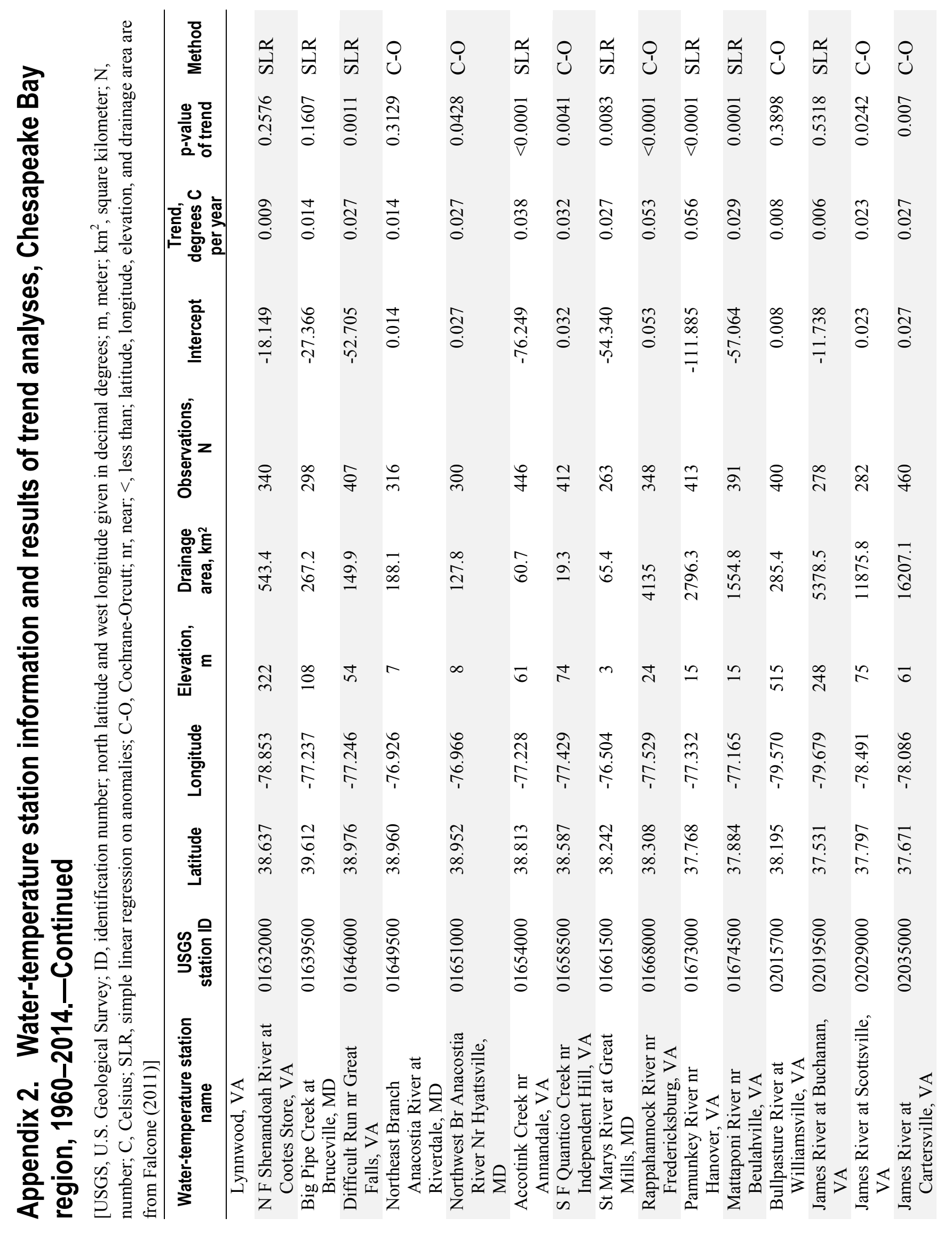




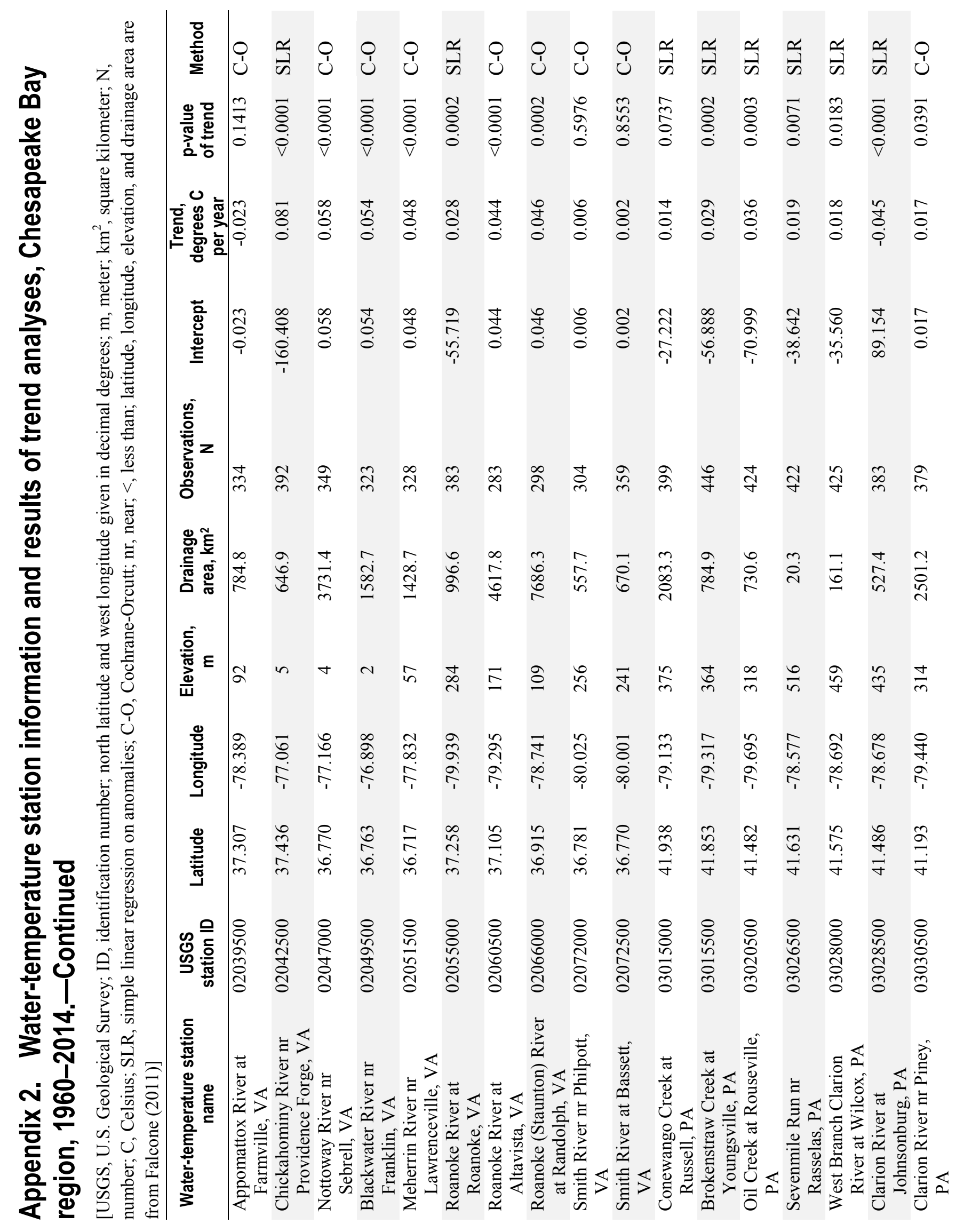




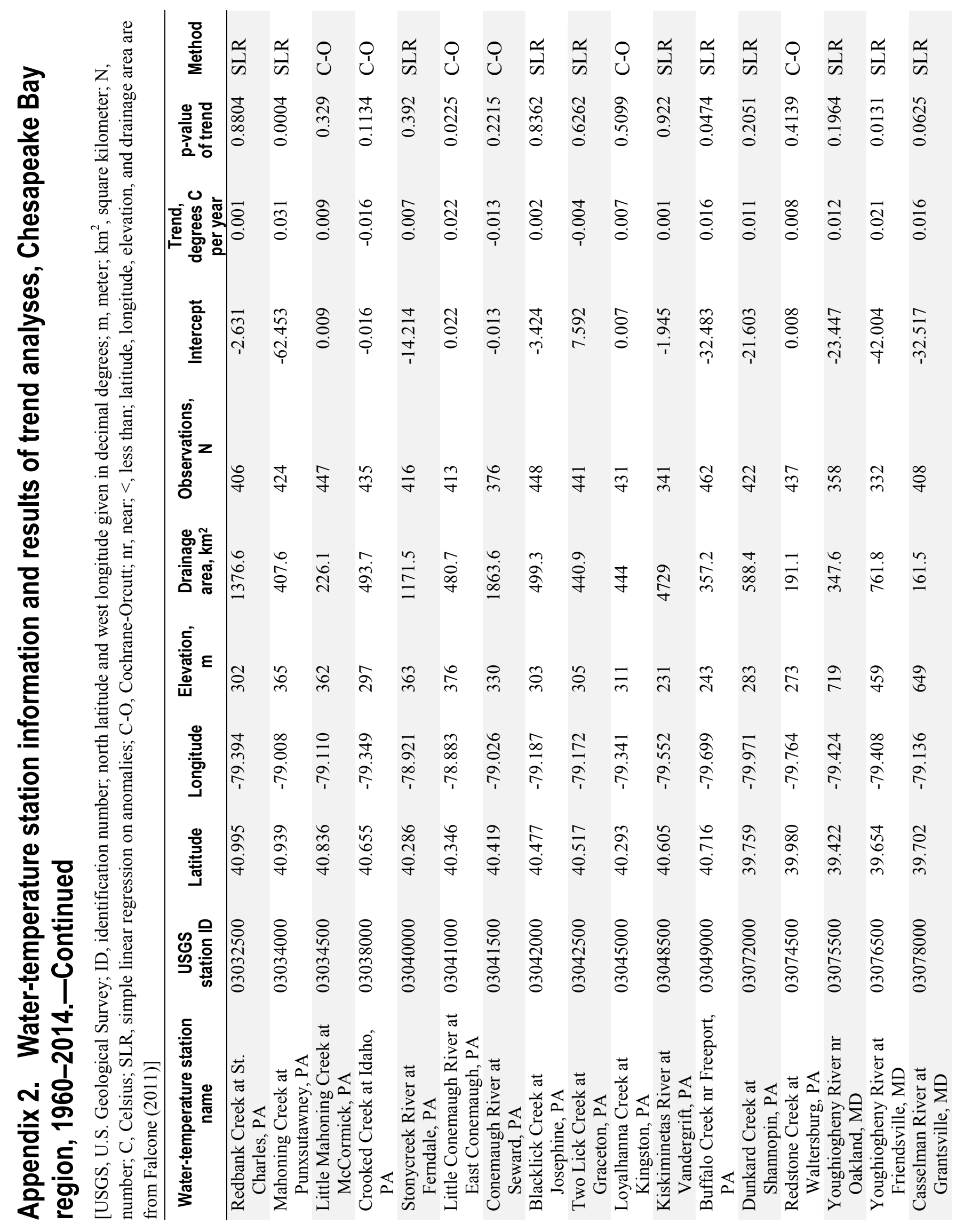




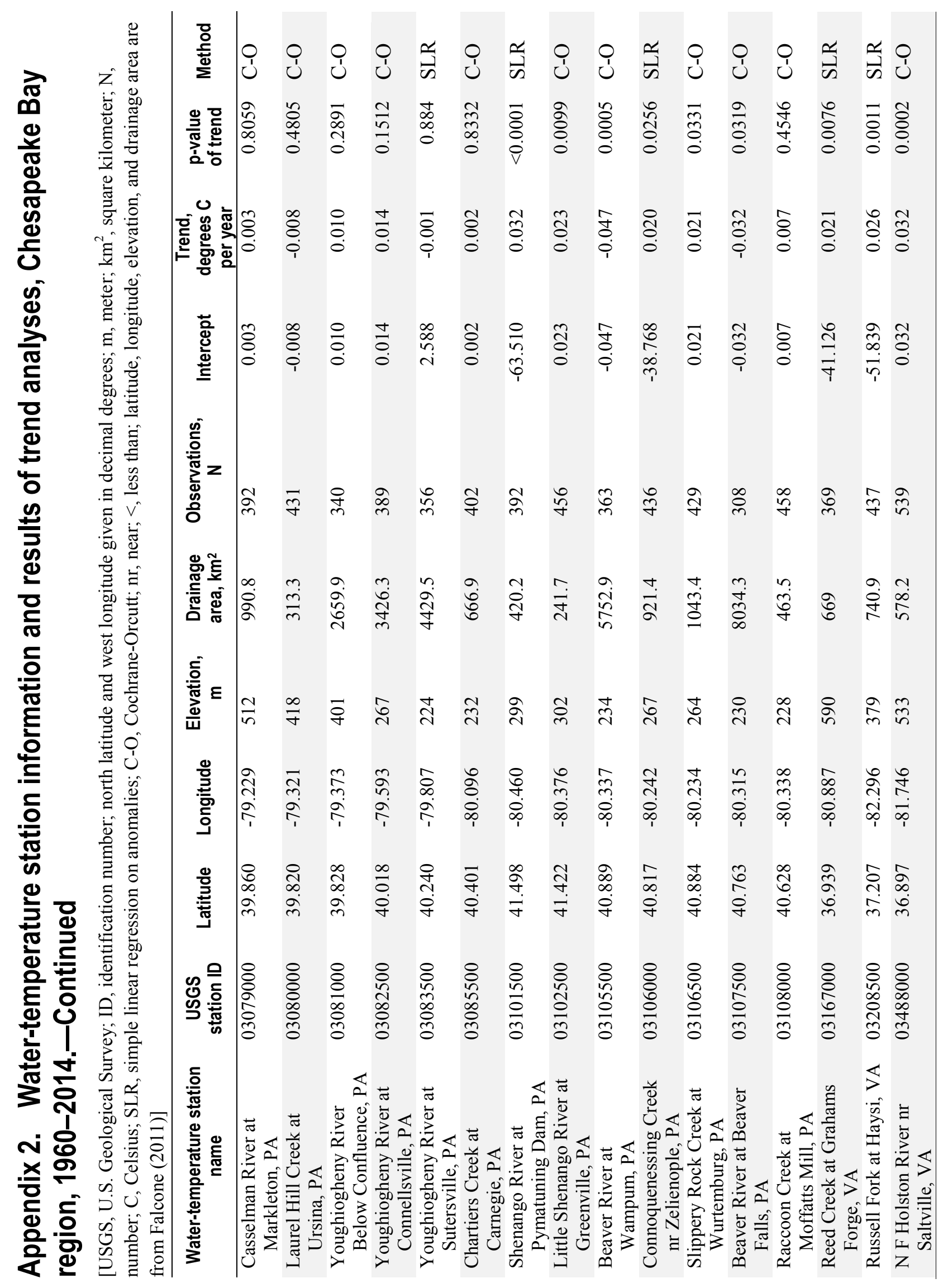




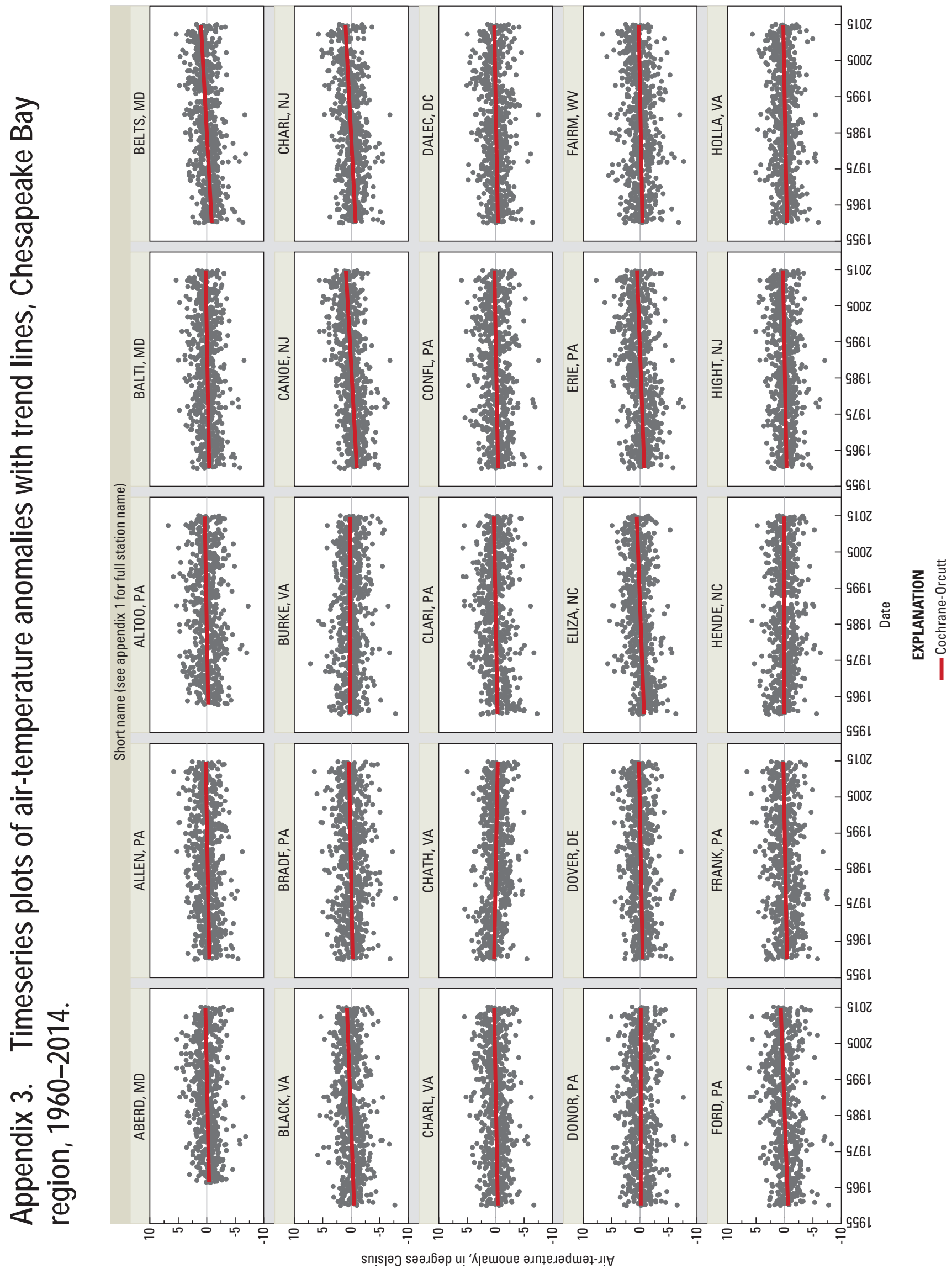




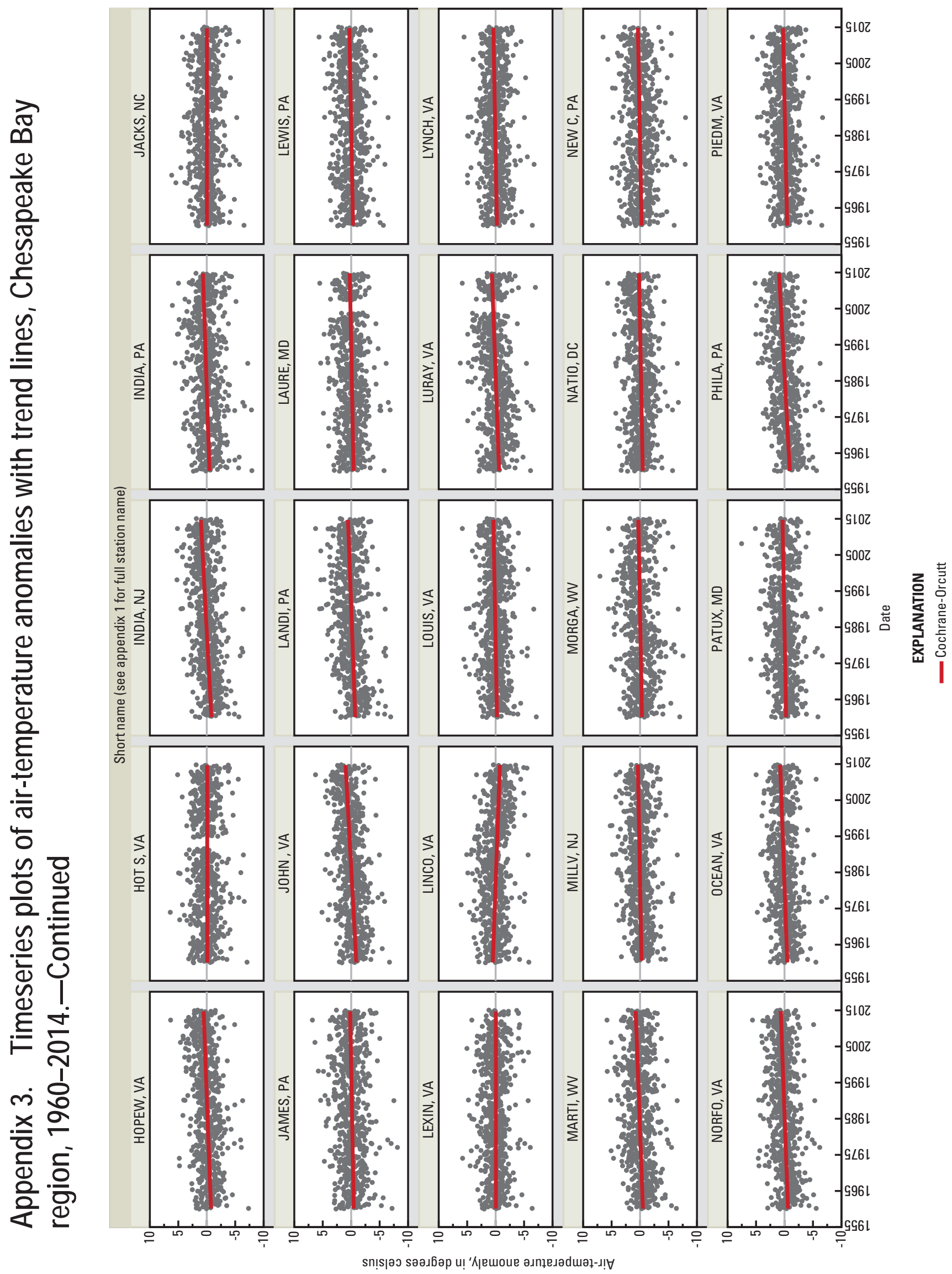




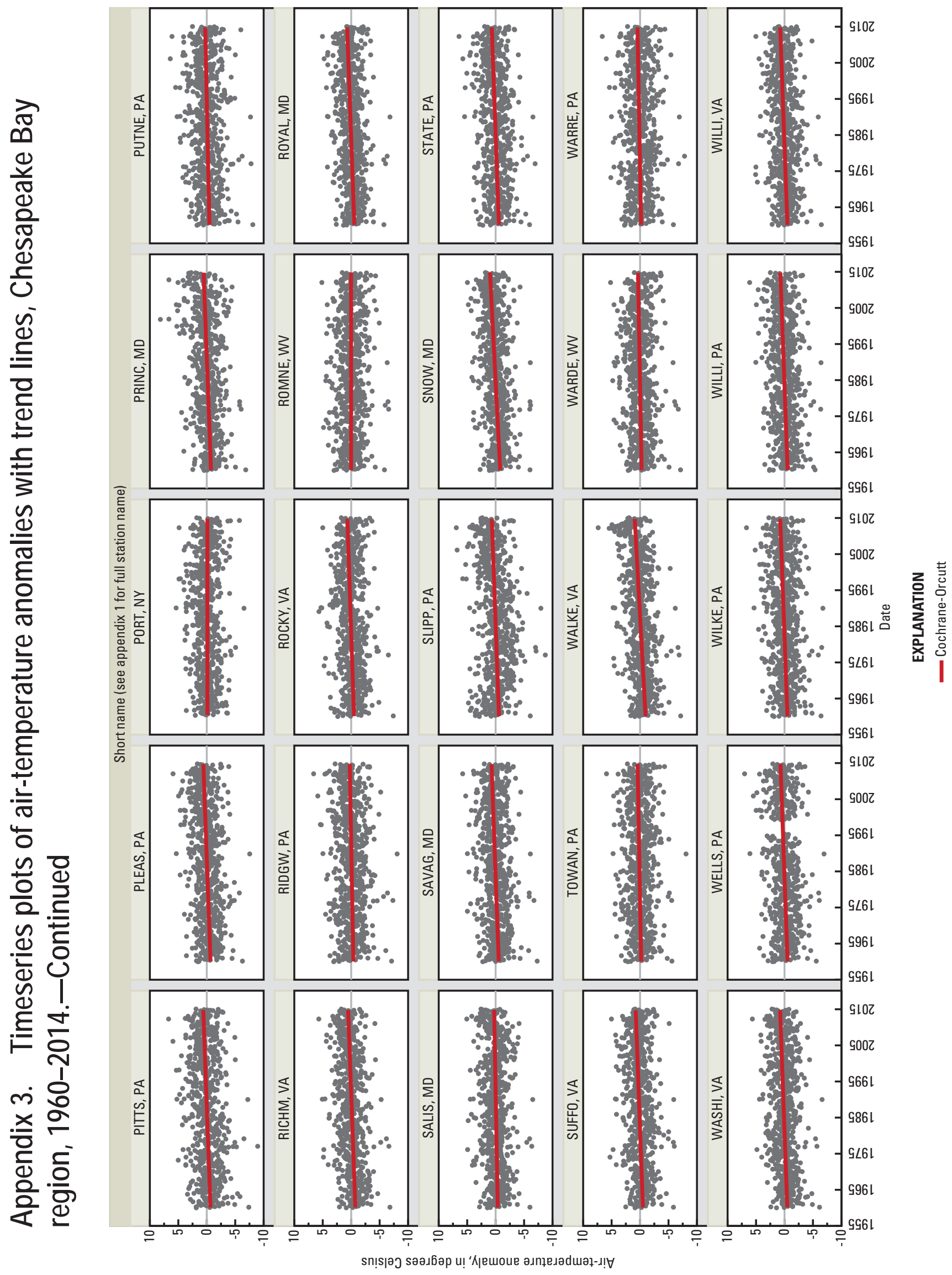




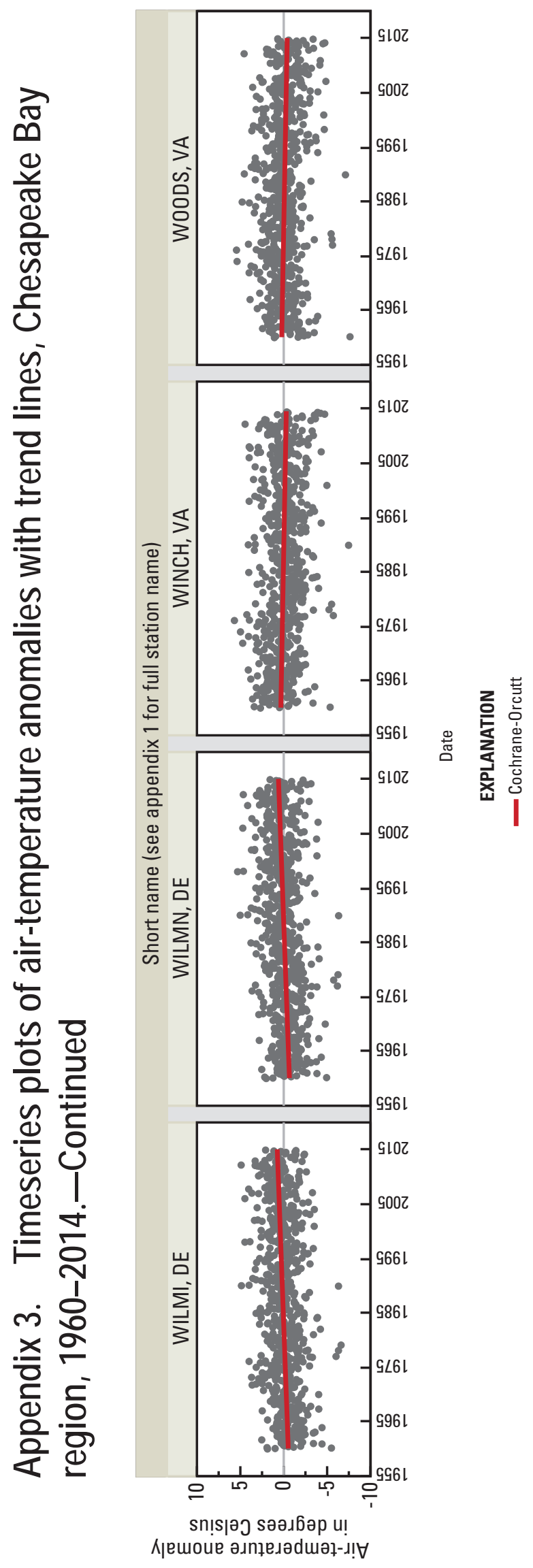




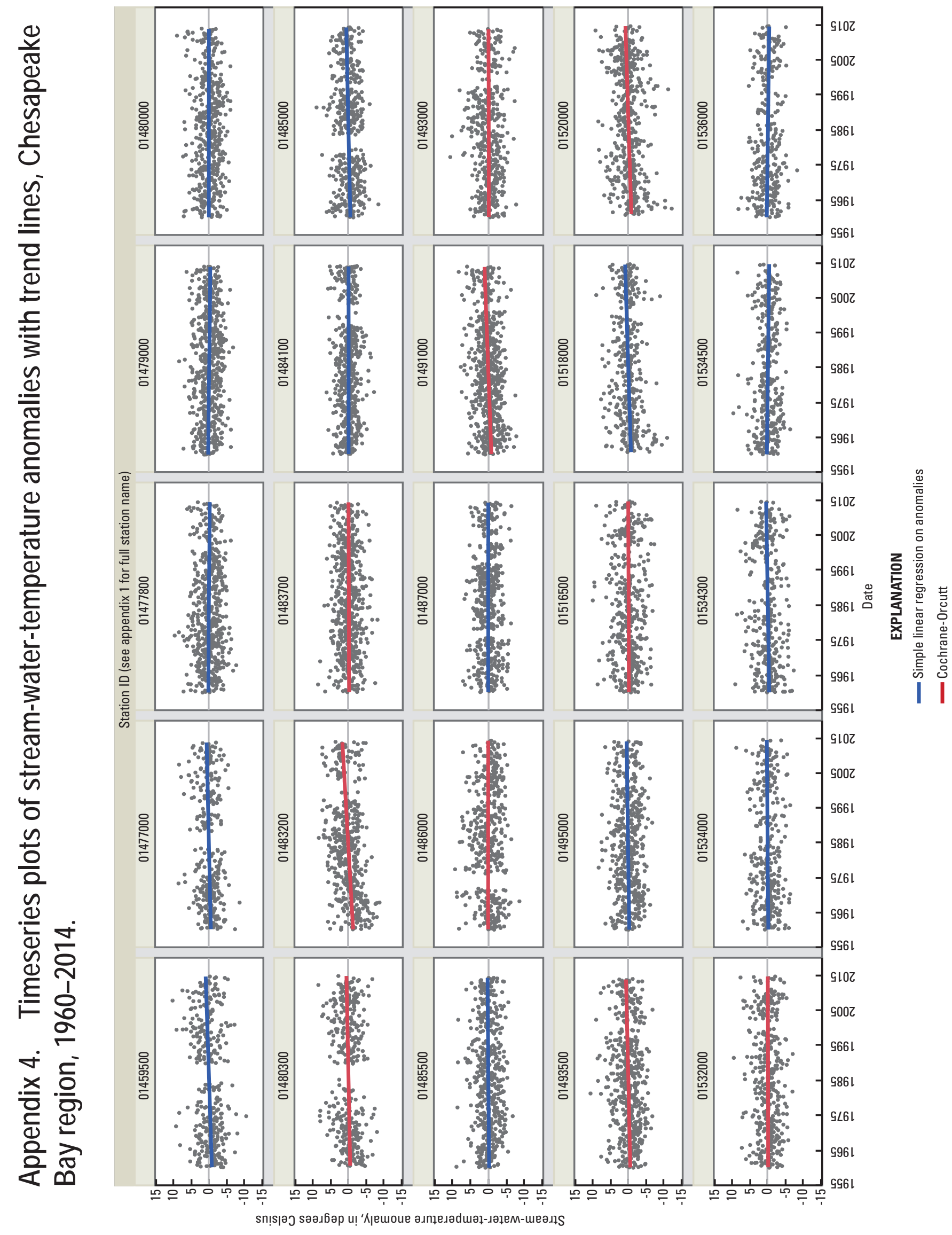




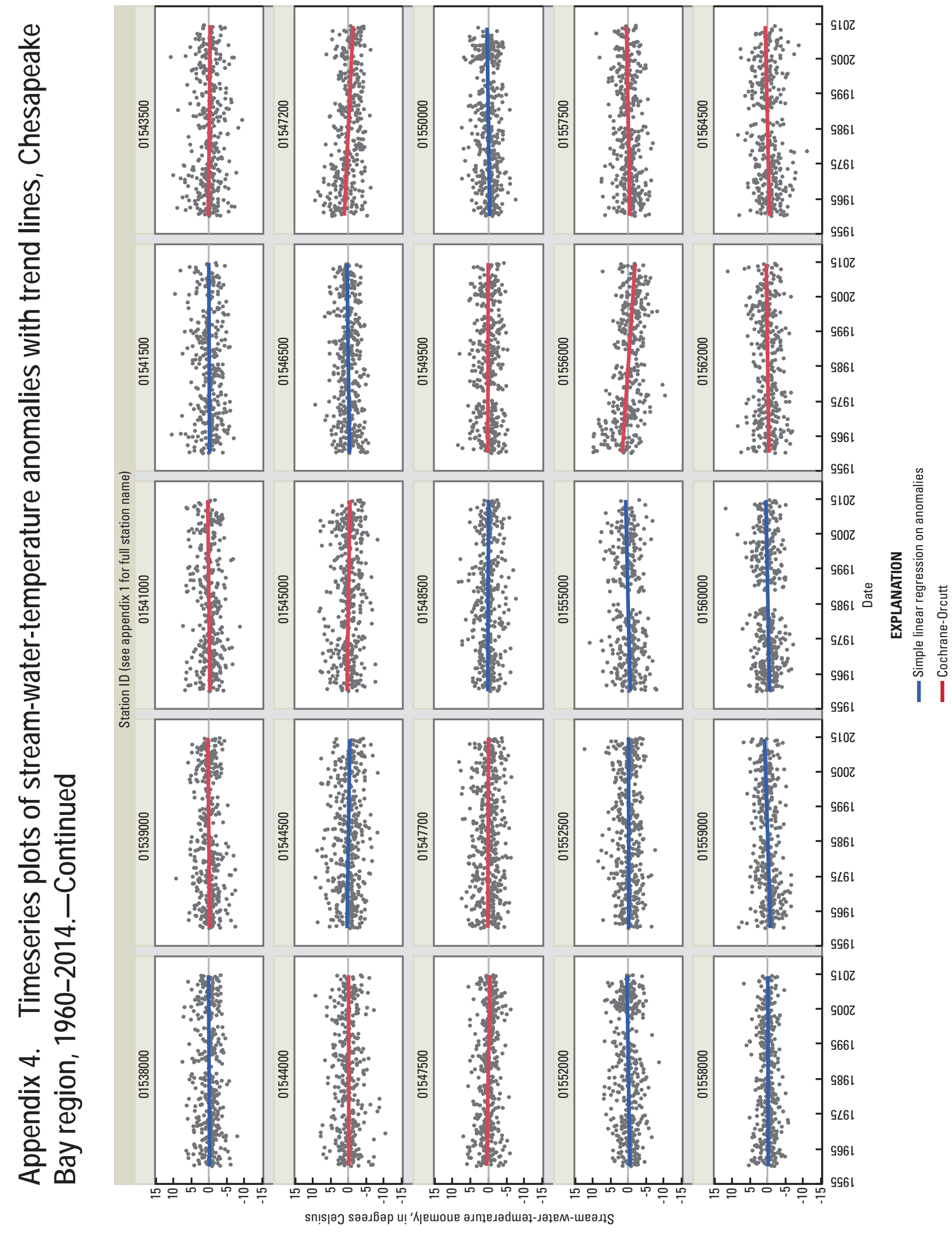




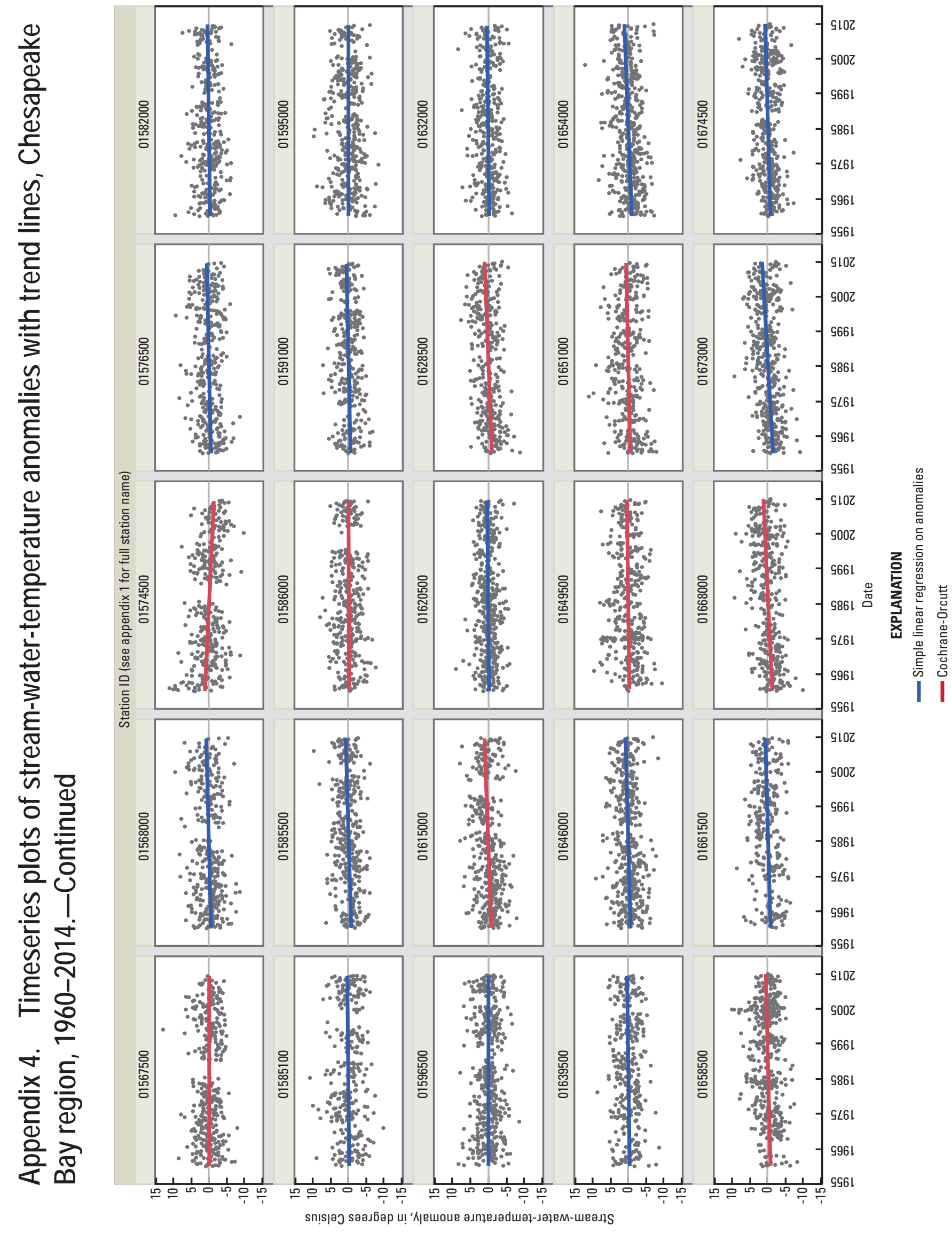




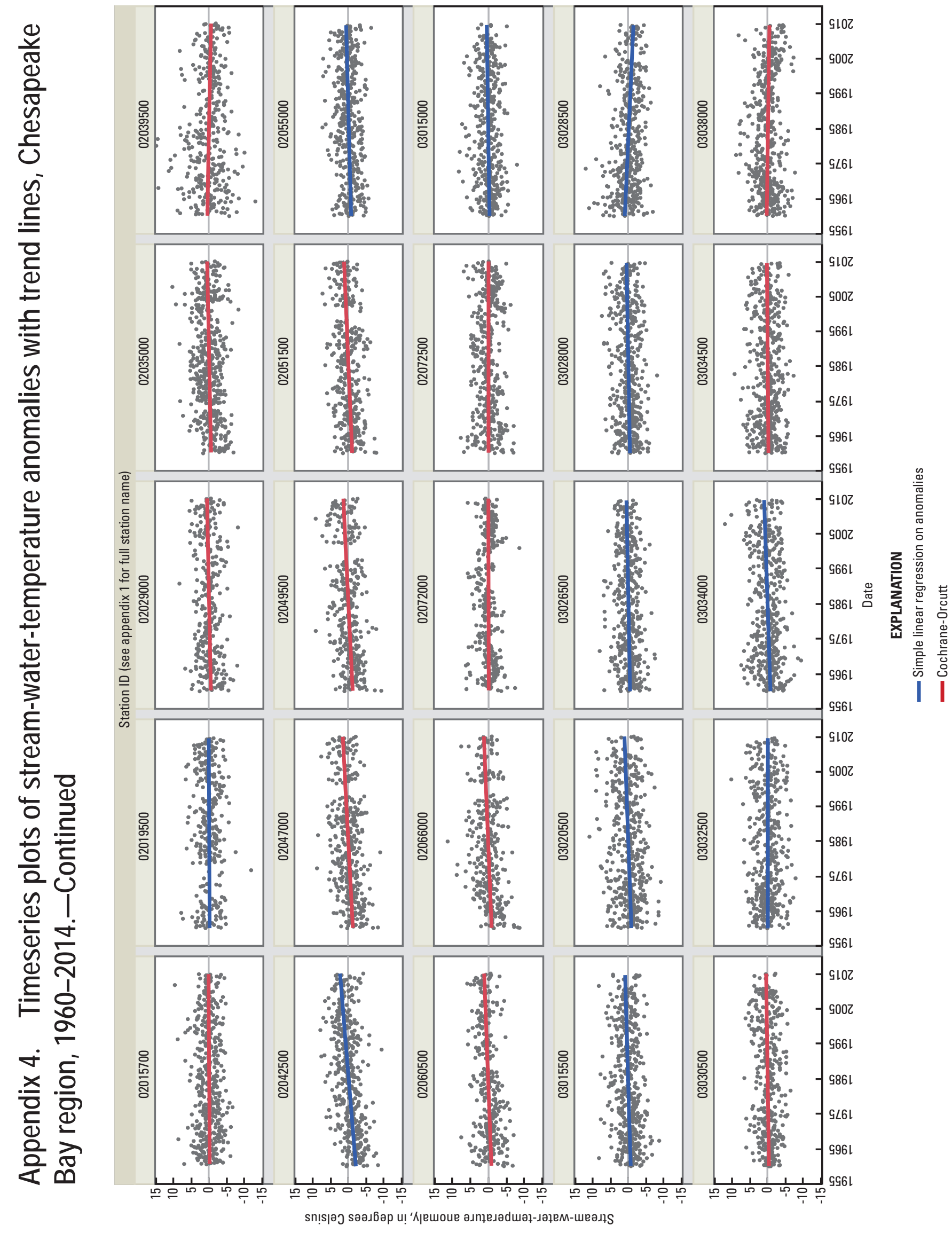




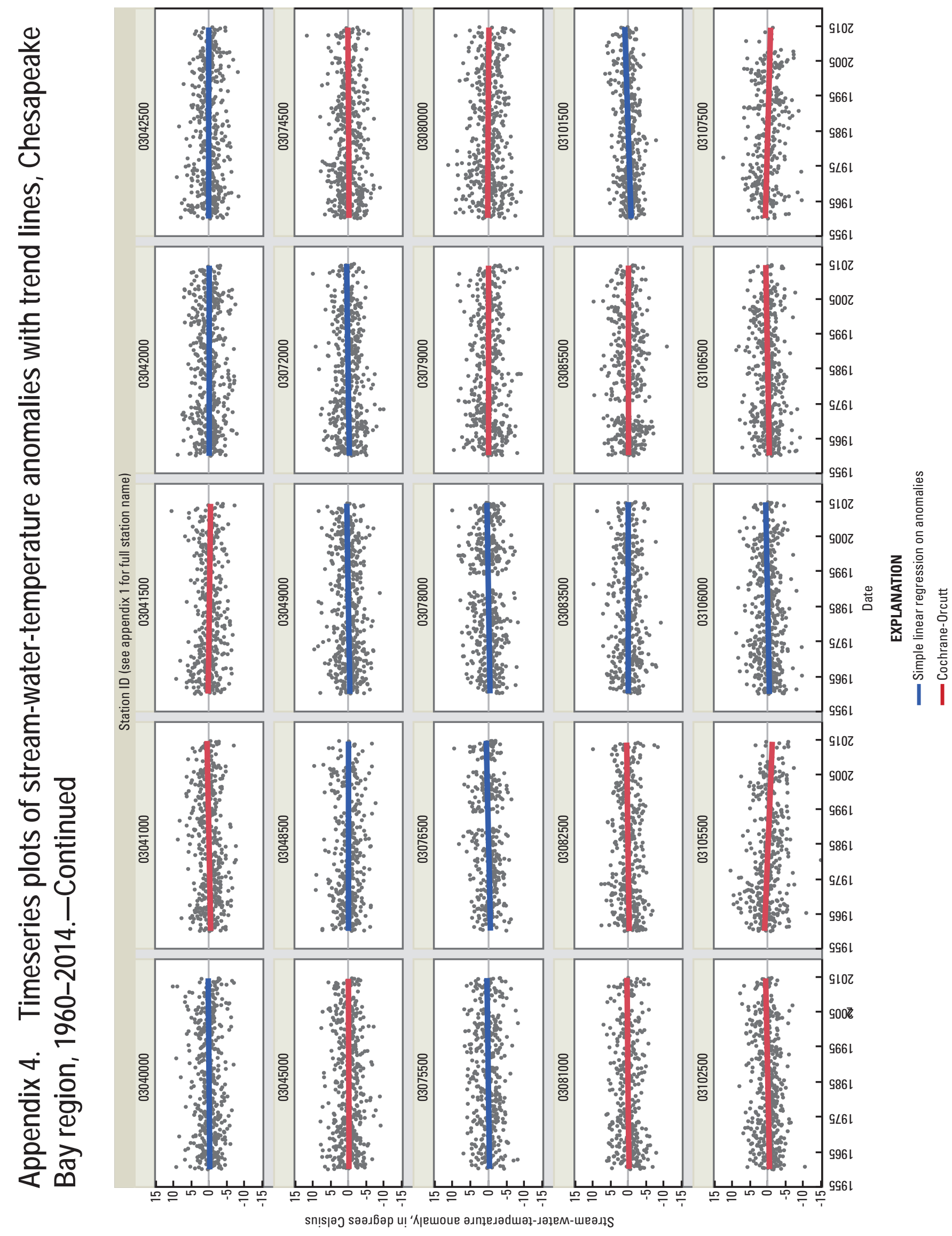




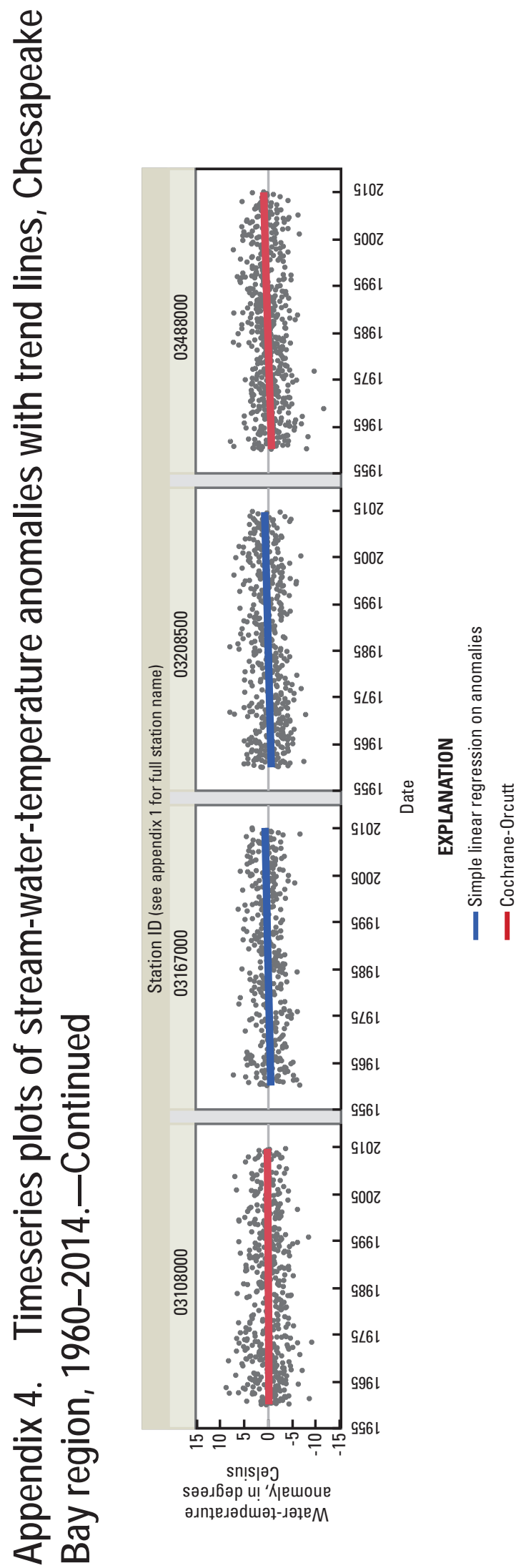


